\title{
Türk Resminde Yemek ve Sofra Betimleri ile Osmanlı Mutfağının Dönüşüm Öyküsü (1839-1950)
}

\section{The Story of the Transformation of Ottoman Cuisine Through Food and Table Depictions in Turkish Painting (1839-1950)}

\author{
İlkay Canan Okkalı ${ }^{1}$ (D), İlona Baytar² (D)
}

Trabzon Üniversitesi, Güzel Sanatlar Fakültesi, Resim Bölümü, Trabzon, Türkiye

${ }^{2}$ TBMM Genel Sekreterliği, İstanbul, Türkiye

ORCID: I.C.O. 0000-0003-1817-4060;

I.B. $0000-0001-8564-5665$

'Sorumlu yazar/Corresponding author: İlkay Canan Okkalı (Dr. Öğr. Üyesi), Trabzon Üniversitesi, Güzel Sanatlar Fakültesi, Resim Bölümü, Trabzon, Türkiye

E-posta: icanikli@gmail.com

Başvuru/Submitted: 16.01.2020 Revizyon Talebi/Revision Requested: 04.05.2020

Son Revizyon/Last Revision Received: 12.05.2020

Kabul/Accepted: 15.05 .2020

Online Yayın/Published Online: 30.06 .2020

Atıf/Citation: Okkali, Ilkay Canan, ve Baytar, llona, "Türk Resminde Yemek ve Sofra Betimleri ile Osmanlı Mutfağının Dönüşüm Öyküsü (1839-1950)". Sanat Tarihi Yıllı̆̆ı - Journal of Art History 29 (2020), 63-88

https://doi.org/10.26650/sty.2020.004

\section{Öz}

19. yüzyıl Osmanlı tarihinde geleneklerin yerini yeni ve modern olana bırakmaya başladığı bir dönemi ifade eder. Dönemin siyasi yapısında görülen değişimler toplum yapısını dolaylı olarak etkileyerek özellikle maddi kültürde bir kırılma meydana getirir. Söz konusu değişimler yemek yeme alışkanlıklarından, kullanılan eşyalara kadar değişimi gündeme getirir. Yemek ve sofra kültürü sosyal, ekonomik ve kültürel pek çok olguyu bünyesinde barındırır, içinde geliştiği toplumun kültürel kimliğinin aktarımında da oldukça önemli rol oynar. Osmanlı mutfağından Cumhuriyet mutfağına geçiş sürecinde modernleşme olgusunun getirdiği yaşam pratikleri, yenilikler ve çelişkiler ile geleneksel sofra adabı bir anda yok olmayacak ve toplumda uzunca bir süre varlığını koruyacak, bir süre sonra da yerini büyük şehirlerde modern olana bırakarak gündelik hayatımızdan çıkarken, kuşkusuz kırsal yerleşimlerde uzunca bir süre daha devam edecektir. Türk resminde yemek ve sofra kültürünün konu olarak alındığı bu çalışmada amaçlanan yemek yeme alışkanlıklarımızın değişimini ve toplumsal yansımalarını Türk ressamlarından seçtiğimiz bazı özgün çalışmalar ile belgelemektir. Çalışma Tanzimat döneminden başlayarak 1950'lilerle sınırlandırılmış; seçilmiş resimler dönemin yemek kültürünü anlatan yemek risaleleri ve romanlarıyla desteklenmiştir. 1950'lerden sonra Türk resminin soyut sanata yönelmesi ve ilerleyen yıllarda kavramsal işlerin yer alması ile yemek ve sofra betimleri farklı göstergelerle okunacak bir yola girer. Dolayısıyla 1960'dan günümüze devam eden süreç, bu çalışmanın kapsamı dışında bırakılmıştır.

Anahtar kelimeler: Türk resmi, Sofra betimleri, Yemek resimleri, Natürmort, Sosyo-kültürel değişim

\section{ABSTRACT}

In Ottoman history, the $19^{\text {th }}$ century is a period when tradition gave way to what was new and modern. The changes observed in the political structure of the period indirectly affected the social structure thus creating a breakup in the material culture in particular. The aforementioned changes bring to light some changes in eating habits. Food and eating culture embodies numerous social, economic and cultural situations. It has a significant role in the cultural identity of a society. During the transition process from the Ottoman cuisine to the Republican cuisine, with everyday practices, novelties and contradictions, 
traditional table manners did not vanish in an instant but continued in society for a long time. In time they vanished from daily life by giving way to modern practices in big cities while continuing their existence in rural regions. The aim of this study on food and eating culture is to substantiate the changes in our eating habits and their social reflections through some distinctive works by Turkish artists which we have chosen. In this study we examine a selection of paintings from the Reform Era (Tanzimat) to the 1950s supported by old food booklets and novels that reveal the food culture of the period. Because of the inclination towards abstract art in Turkish painting after the 1950 s and the emergence of conceptual works in the following years, food and table depictions should be studied by means of different indicators. Therefore the process from the 1960s onwards is left out of the scope of this study. Keywords: Turkish painting, Table depictions, Food paintings, Still-life, Socio-cultural transformation 


\section{Giriş}

Sanayi devrimi ve sömürgecilik Avrupa'nın 19. yüzyılda kurduğu otoriteye yeni bir düzen getirir. Avrupa'nın dışında kalan tüm devletler ise yönetim sistemlerinden sosyal yaşamlarına kadar Avrupa'yı takibe başlarlar. ${ }^{1}$ Osmanlı Devleti ise bu süreçte kendisini yeniden tanımlama ve devletin devamlılığı için yeni düzenlemeler yapmak isteği ile yüzünü Batı'ya dönerek Avrupa devletleri ile mütekabiliyet esasında ilişkiler geliştirmeye başlar. Siyasi anlamda başlayan ilişkiler Osmanlı protokol yapısında da değişimi getirirken beraberinde mutfak kültürünü de etkileyecektir. Bu anlamda sosyokültürel yapıdaki ilk değişim matbah-1 amire ve pişen yemeklerin sunumu ile başlayacaktır.

Claude Lèvi-Strauss, haşlama, 1zgara ve tütsüleme başta olmak üzere, pişirme tekniklerinin anlam şemasını kurduğu makalesinde mutfağın, toplumun yapısını farkında olmaksızın tercüme ettiği bir dil olduğunu; toplumun çelişkilerini de bu dille yine bilinçsiz bir biçimde açık ettiğini yazar. $^{2}$ Nitekim yemek yemek toplumların en önemli kültürel belirleyicisidir. Osmanlı Devleti 19. yüzyılın ilk yarısına kadar geleneksel sisteminden getirdiği yeme alışkanlıklarını devam ettirir. 1839'da Tanzimat Fermanı, 1856'da ise Islahat fermanlarının ilanına kadar devam eden sofra geleneği 19. yüzyılın sosyokültürel yaşamdaki değişimi ile çember düzendeki sofra yerini Batı esaslı sofra düzenine bırakırken önceden işlevi tanımlanmış mekânları da gündeme getirmiştir.

Geleneksel Osmanlı mutfağı Orta Asya'dan getirdiği geleneklerin göç ettiği yerlerdeki kültürler ile kaynaşmasıyla ortaya çıkan zengin bir mutfaktır. Asıl gelişimi ise saray mutfağının çevresinde gelişerek şekillenir. Ancak ortaya iki mutfak kültürü çıkarır; saray mutfağı ve halk mutfağı. Tüketilen malzemelerden, pişirilen yemeklere, kurulan sofralardan kullanılan araç gereçlere kadar görülen ikili kültür önce dönemin romanlarında ele alınır. Resmin teması olması ise belirli bir zaman alır. Aslında Türk tasvir sanatının kaynağını aldığı minyatürlerde yemek ve sofra betimlerine, ziyafet sofralarına yer verilmiş olsa da $^{3}$ Batı kaynaklı Türk resminin betimlediği öncelikli konular arasında yer almaz. Bu anlamda 19. yüzyılın ikinci yarısından itibaren mutfağa neyin girdiği ilk olarak Natürmort betimlerde görülür. Her ne kadar Natürmortlar ayrı bir resim türü olsalar da dönemin meyve ve sebzelerini göstermesi açısından oldukça önemli belge niteliğine sahiptirler. Nitekim sofrayı ve yemekleri gösteren ayrıntılı betimlere yer vermek için bir süre daha beklemek gerekecektir.

$\mathrm{Bu}$ makale betimsel modele dayalı nitel bir araştırmadır. Veri toplaması arşiv belgeleri, literatür taraması temel nitelikli tarih ve sanat tarihi kitapları ile birlikte konuyla ilgili makale ve tezlerin incelenmesiyle yapılmıştır. Tanzimat döneminden itibaren cumhuriyetin ilk yarısına

1 Hakan T. Karateke, Padişahım Çok Yaşa! Osmanlı Devletini Son Yüzyılında Merasimler, Kitap Yayınevi, İstanbul 2004, s. 10.

2 Claude Lèvi-Strauss, “Le Triangle Culinaire”, L’Arc, n.26, 1965, s.29'den aktaran Burak Onaran, Mutfak Tarih Yemeğin Politik Serüveni, İletişim Yayınları, İstanbul 2015, s.7.

3 Bu konuyla ilgili ayrıntılı bilgi için bk. Gizem Tatlıcı, Görsel Belleğin İzinde Türk Resminde Yemek Kültürü, Işık Üniversitesi Sosyal Bilimler Enstitüsü Sanat Bilimi Programı (Yayımlanmamış) Doktora Tezi, İstanbul 2018, s.165-199. 
uzanan süreçte seçilen resimler üzerinden yemek ve sofra kültürü ele alınmış, dönemin yemek risaleleri ve romanlarıyla desteklenmiştir.

\section{Sofra ve Yemek Betimlerinin Ortaya Çıkışı}

Ziyafet ve sofra betimleri Antikçağa tarihlenen Pompei ve Herculanum evlerinin dekorasyonlarına kadar uzanır. ${ }^{4}$ Batı resminde Ortaçağ' dan itibaren yemek ve sofra ile ilgili betimler olsa da bunlar daha çok ikonografik anlamlar içeren resimlerden oluşur. ${ }^{5}$ Nitekim Giotto'nun Son Akşam Yemeği $(1306)^{6}$ tablosu sadece dini bir içeriğe sahipken, Paulo Veronese'in Kana Düğünü (1563) ${ }^{7}$ resmi dini içerikli bir konu olmasına karşın dönemin yemeklerini göstermesi açısından dikkate değerdir. Dini olmayan yemek ve sofra teması ise Rönesans döneminden itibaren görülmeye başlar. Limbourg Kardeşler'in 15. yüzyıl başında betimlediği Ocak: Berry Dükü'nün Ziyafeti ${ }^{8}$ ile Sandro Botticelli ve atölyesi tarafından yapılan Nastagio degli Onesti Hikâyesi: Evlilik Ziyafeti (1483) resimleri üzerinde yiyeceklerle donatılmış masalar ile bu konuyu en iyi örnekleyen çalışmalar arasında yer alırlar. ${ }^{9}$ 16. yüzyıl sonlarına doğru İtalya' da günlük yaşam sahneleri resme konu olmaya başlar. İlk örneklerden Annibale Carracci'nin Fasulye Yiyen resmi sıradan bir köylünün yemeğini gerçekçi bir üslup ile ele alır. ${ }^{10}$ 17.yüzyıl Hollanda'sında ise tür ressamlığının oluşması ile gündelik yaşamda sofra resimleri daha sık görülmeye başlar. Nicolas Maes'in Dua Eden Yaşlı Kadın (1655), Jan Steen'in Mutlu Aile (1688) tabloları gündelik yaşam içerisindeki sofra ve öncesinde dua etmek gibi ritüelleri örnekler. ${ }^{11}$ Erken dönem Rönesans resimlerinden günümüze kadar açık havada yenen yemekler, taverna, kafe, çay salonları ya da restoranlardaki yemek sahneleri, sıradan insanların sofraları ya da seçkin yemek odaları gibi her türden ortamın ve sınıfın resmi yapılır.

4 Silvia Malaguzzi, Food and Feasting Art, translated by Brian Phillips, The J.Paul Getty Museum, Los Angeles, Hong Kong 2008, s.102.

5 Silvia Malaguzzi, a.g.e., s.10.

6 Bedrettin Cömert, Giotto'nun Sanatı, De Ki Yayınları, İstanbul 2018.

7 https://www.louvre.fr/en/oeuvre-notices/wedding-feast-cana (Erişim Tarihi 11.05.2020)

8 Silvia Malaguzzi, a.g.e., s.317; Tatlıcı, a.g.e., s.114. Dük resmin sağında mavi renkli giysisiyle masada otururken betimlenmiştir. Ziyafet masasının üzeri yiyeceklerle donatılmıştır. (Resim bilgisi: Limbourg Kardeşler, Ocak: Berry Dükü 'nün Ziyafeti, 1413-1416, Berry Dükü'nün Çok Zengin Saatlerinden minyatür sayfası, Chantilly, Conde Müzesi.)

9 Silvia Malaguzzi, a.g.e., s. 318; Tatlıc1, a.g.e., s.117,118. Ravenna asillerinden olan Nastagio degli Onesti, Giovanni Boccaccio'nun Decameron’unda geçen yüz kısa öykünün birinin kahramanıdır. Beşinci günün sekizinci hikâyesidir ve Nastagio'nun karşılıksız sevgisini anlatır. Botticelli bu hikâyeyi Antonio Pucci'nin oğlu Giannozzo'nun Lucrezia Bini’yle dügünü için siparişi üzerine dört bölüm halinde resimler. İlk iki resim kendilerini romandaki olaylarla sınırlarken, üçüncü ve dördüncü paneller Ravenna'da gerçekleşen hikâyeyi Floransa'daki düğüne çevirir. Damadın babası Antonio Pucci, konukların ortasında üçüncü resim üzerinde tasvir edilir ve dördüncüsünde de şehirde bir dizi önemli halk figürü de gösterilir. Dört resim Botticelli’ye ait olsa da, uygulama kısmen asistanlarına, özellikle de ilk üç resim için Bartolomeo di Giovanni’ye ve dördüncü için Jacopo da Sellaio'ya emanet edilmiştir. (Resim bilgisi: Botticelli, Nastagio degli Onesti Hikayesi: Evlilik Ziyafeti (dördüncü bölüm), 1483, panel üzerine tempera, $83 \times 142 \mathrm{~cm}$, özel koleksiyon.)

10 Tatlıc1, a.g.e., s.129. (Resim bilgisi: Annibale Carracci, Fasulye Yiyen, 1583, Tuval üzerine yağlıboya, 57x68 cm, Galleria Colonna, Roma.)

11 Silvia Malaguzzi, a.g.e., s.110,146. (Resim bilgisi:Nicolas Maes, Dua Eden Yaşlı Kadın, 1655, tuval üzerine yağlıboya, 134x113 cm, Rijkmuseum, Amsterdam. Jan Steen, Mutlu Aile, 1668, tuval üzerine yağlıboya, 110,5x $141 \mathrm{~cm}$, Rijkmuseum, Amsterdam.) 
18. yüzyıldan itibaren özellikle Fransa'da saray ve çevresinde akşam yemeği davetlerin en gözde etkinliği haline gelir. Kahvaltı ise içerik açısından toplumlara göre en çok farklılık gösteren öğündür. Boucher'in Kahvaltı (1739), Gustave Courbet'nin Av Pikniği (1858), Claude Monet'nin Kahvaltı (1868), Edouard Manet'nin Stüdyoda Ö̆ğle Yemeği (1868) Albert-Auguste Fouri'nin Yport'taki Düğün Şöleni (1886), Jules-Alexandre Grün'ün Akşam Yemeğinin Sonu (1913) resimlerinde ait oldukları dönemlerin yiyecek ve sofra kültürüne dair detayları, sosyal yaşamları ve dünya algıları görülür. ${ }^{12}$

18. yüzyıla kadar minyatür sanatı ile örneklerini veren Türk tasvir sanatı, kaynağını kitap resimlerine dayanan Türk-İslam geleneğinden alır. Batı kaynaklı resim ise 19. yüzyılın ilk yarısına tarihlenir. Aslında Türk resim sanatı 19. yüzyılda askeri ve sivil okullara konulan perspektif dersleriyle ilk örneklerini vermeye başlar. ${ }^{13}$ Ağırlıklı olarak manzara temasının yanında tabiat-ı sakine denilen Natürmort da çalışılmaya başlanır. İlk örnekler fotoğraflardan ve kartpostallardan renklendirme yöntemiyle yapılır ki burada önemli olan iyi gözlem yeteneği ile doğru perspektifi yakalayabilmektir. Form ve hacim düzenlemelerinde ise geometriden yararlanılır. Daha çok manzara teması çalışılırken Natürmort resimler de asker ressamların betimlerinde karşımıza çıkmaya başlar. İlk Natürmort çalışan sanatçılar arasında Osman Nuri Paşa (1839-1861) ${ }^{14}$, Ahmet Şekur (1856 İstanbul-?) ve Ahmet Ziya (Akbulut) (1869-1938) yer alırken onları, Şeker Ahmed Paşa (1841-1907, Süleyman Seyyid (1842- 1913) ve Hüseyin Zekâi Paşa (1860- 1919) takip eder. Bu anlamda Natürmort resimler henüz iç mekânların, yemek ve sofraların betimlenmediği bir dönemde dönemin meyvelerini göstermesi açısından dikkate değerdir.

Şeker Ahmed Paşa ve Süleyman Seyyid aynı dönemin sanatçılarıdır, ancak betimledikleri temalar ile birbirlerinden ayrılırlar. Sanatçıların resimleri üzerinde ayrıntılı bir çalışma yapıldığında söz konusu sanatçıların da hayali değil de gördügünü resmetmiş olduğu varsayıldığında betimlerindeki meyveler de aslında o an için gördükleri ile sınırlı olmalıdır. Nitekim Şeker Ahmed Paşa, saray için çalışır, Sultan II. Abdülhamid döneminin yaver ressamıdır. ${ }^{15}$ Dolayısıyla onun betimleri çağdaşı diğer sanatçılardan daha zengin içerikli kompozisyonlardan oluşur. Kış ve yaz meyvelerinin bir arada betimlenmiş olması sarayda tüketilen meyvelerin ve sebzelerin

12 Silvia Malaguzzi, a.g.e., s. 89, 97, 87, 90, 108, 96. (Resim bilgileri: François Boucher, Kahvaltı, 1739, tuval üzerine yağlıboya, 81.5 x $61.5 \mathrm{~cm}$, Louvre, Paris. Gustave Courbet, Av Pikniği, 1858,tuval üzerine yağlıboya, $207 \times 325 \mathrm{~cm}$, Wallraf-Richartz Museum, Köln, Almanya. Claude Monet, Kahvaltı, tuval üzerine yağlıboya, 150 x 230 cm, Städelsches Kunstinsitut, Frankfurt. Albert-Auguste Fouri, Yport’taki Dügü̈n Şöleni, 1886, tuval üzerine yağlıboya, Musée des Beaux-Arts, Rouen, Fransa. Jules-Alexandre Grün, Akşam Yemeğinin Sonu, 1913, tuval üzerine yağlıboya, $215 \times 320 \mathrm{~cm}$, Musée des Beaux-Arts, Fransa.)

13 Ahmet Kâmil Gören, "Türk Resminin Önemli Bir Odağı: Saray Koleksiyonu, İhtişam ve Tevazu: Padişahın Ressam Kulları, (Haz. Gülsen Sevinç Kaya), İstanbul, TBMM Milli Saraylar, 2012, s. 15-39.

14 Osman Nuri'nin, 1859'da henüz öğrenciyken Saray'a yaver olarak alınmasıyla başlayan ve Sultan Abdülaziz (1861-1876) döneminde gelişen, kısaca "Yaver Ressamlar” olarak (Yâverân-1 Hazret-i Şehriyâri) görevlendirilen Osman Nuri Paşa (1839-1861), Yusuf Ziya Paşa (1840-1908), Şeker Ahmed Ali Paşa (1841-1907), Servili Ahmet Emin [Surûrîli] (1845-1891), Hüseyin Zekâi Paşa (1860-1919) gibi asker-ressamların varlığıyla birlikte "Saray Ressamlığı” kurumu şekillenmeye başlamıştır. Ahmet Kamil Gören, a.g.e., s.16, 18)

15 Detaylı bilgi için bkz. Gören, Ahmet Kamil, "(Şeker) Ahmed Ali Paşa’yı Yazmak”, Şeker Ahmed Paşa 18411907, (Haz. Ö.Taşdelen, İ.Baytar), Milli Saraylar Yayınları, İstanbul 2008, s.17-69. 
mevsimsiz olmasından kaynaklanır. Nitekim Osmanlı arşiv kayıtlarında yer alan belgeler takip edildiğinde mutfak defterlerinde ayrıntılı olarak yiyecek girişleri takip edilebilir. ${ }^{16}$

Şeker Ahmed Paşa'nın Narlar ve Üzümler’i (F.1) kompozisyonu oluşturan meyvelerle sanatçının mutfağında ya da saray mutfağında gördüklerine işaret eder. Üzüm, kavun ve nar bir aradadır. Yine Şeker Ahmed'e ait bir başka çalışmasında da Blçaklı Natürmort benzer bir kompozisyonu tekrarlar. Üzüm, armut, kesilmiş bir karpuz ile mandalina birlikte resmedilmiştir. Yaz ve kış meyvelerinin bir arada kullanılmış olması sarayın mutfağının zenginliğine işaret eden bir ayrıntı olsa gerektir. Zamanını sarayda geçiren sanatçının bunları betimlemiş olması da son derece doğal olmalıdır.

Portakal Osmanlı sarayında ve İstanbul mutfağında 18. yüzyıldan itibaren tanınmaya başlar, mandalina ise 19. yüzyılın sonunda Osmanlı mutfağında yerini alır. Muz ve ananasın mutfağa giriş tarihi ise 19. yüzyılın sonlarına tarihlenir. ${ }^{17}$ Dolayısıyla 19. yüzyılın ikinci yarısından itibaren tanınan mandalina daha önceki dönem betimlerinde karşımıza çıkmazken, 18. yüzyıldan itibaren mutfakta yerini alan portakal betimleri daha yaygın olacaktır. Dolayısıyla Süleyman Seyyid de daha çok soyulmuş portakallar ile karşımıza çıkar. Portakallı Natürmort resminde (F.2) dilimlenmiş bir portakalı betimlemiştir.

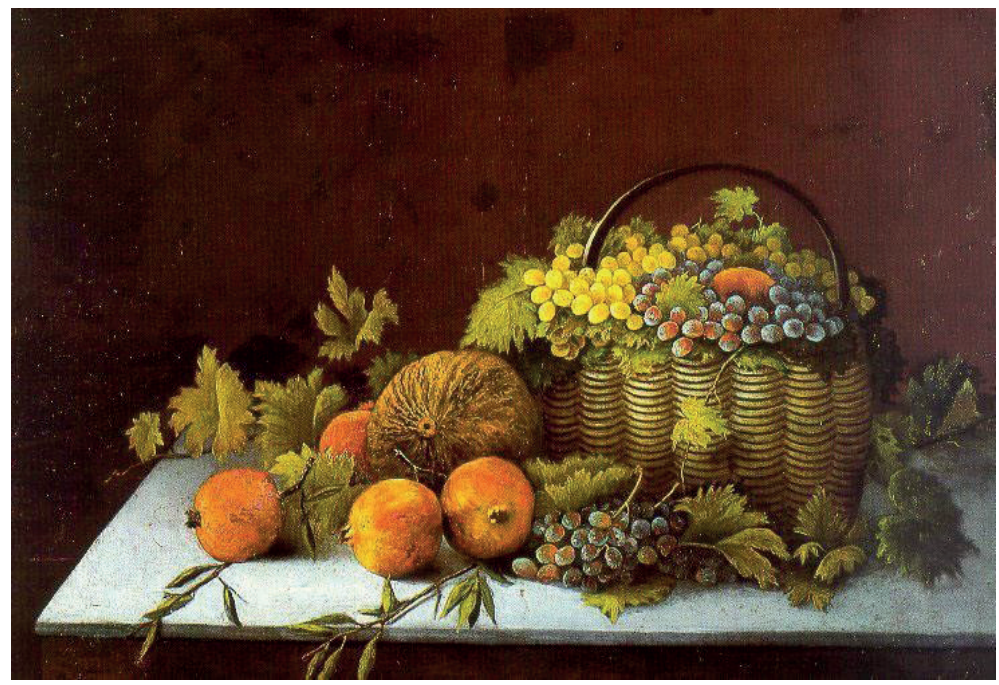

F. 1: Şeker Ahmed Paşa, Narlar ve Üzümler, tuval üzerine yağlıboya, 89x130 cm. Ankara Resim Heykel Müzesi (Şeker Ahmed Paşa (1841-1907), (Haz: Ö. Taşdelen, İ. Baytar), Milli Saraylar, İstanbul 2007, s.168)

16 Osmanlı Arşivlerinde çok sayıda mutfak defteri mevcuttur. Konuya dair bilgi vermesi açısından bkz. BOA, HH. d. 1060, Meyve Defteri H. 20 Eylül 1327 / M. 6 Ekim 1909.

17 Özge Samanc1, “İmparatorluğun Son Döneminde İstanbul ve Osmanlı Saray Mutfak Kültürü”, Türk Mutfağı, Kültür ve Turizm Bakanlığı Yayınları, Ankara 2015, s. 207. 


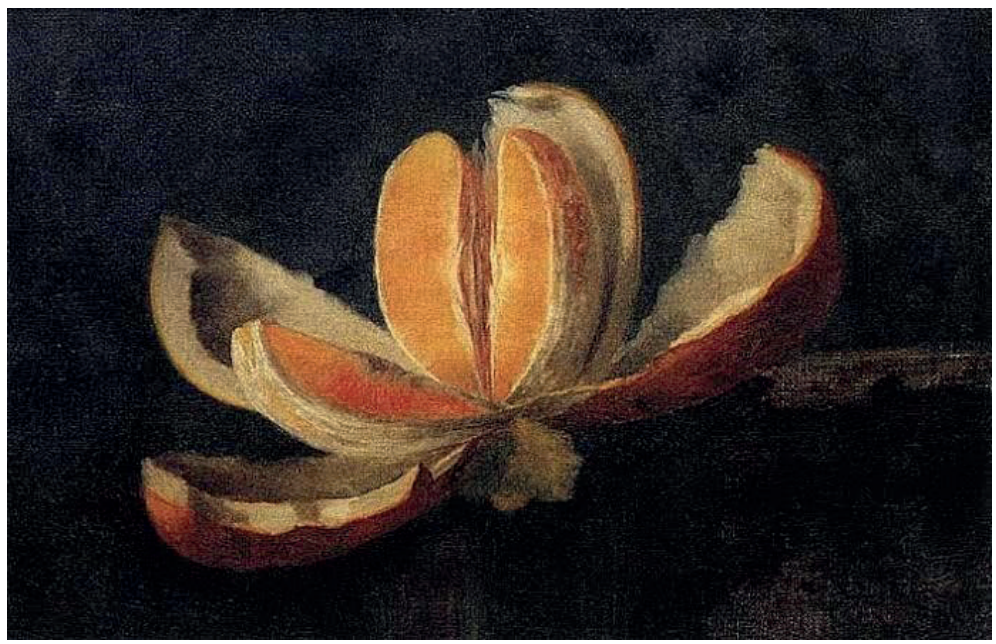

F. 2: Süleyman Seyyid, Portakallı Natürmort, 1901, Osmanlıca İmzalı ve Tarihli (sağ alt), tuval üzerine yağlıboya, $26.5 \times 40.5 \mathrm{~cm}$, Ferda -İbrahim İper Koleksiyonu, (Ed.Ferit Edgü, Batı'ya Yolculuk, Türk Resminin 70 Yıllık Serüveni (1860-1930), SSM 16 Nisan30Haziran 2009, s.61)

\section{Türk Resminde Sofra Betimlemeleri}

19. yüzyllın tüketilen meyvelerini gösteren Natürmortların yanında ne yazık ki bir sofra betimine yer verilmez. Osmanlı'da sofra konusu önce minyatür betimlerinde görülür uzun yıllar sonra da Batılı anlamda tuval resimlerinde yerini alır. Türk kültüründe yenilenin içilenin gösterilmesi yaygın değildir. Dolayısıyla ilk dönem sanatçılarının da bu konudan uzak durmuş olmaları büyük intimal taşır. Bununla birlikte sadece tabiatı resmetme amacıyla çalışılan Natürmortlar ise dolaylı olarak bize mutfak hakkında bilgiler verirler. Sofra, Osmanlı'da belirli bir mekânda kurulmaz, o an için uygun olan ortamda küçük bir iskemle üzerine yerleştirilen sini yemek sofrasını oluşturur. Batılılaşma dönemine kadar devam eden bu geleneği Suraiya Faroqhi şöyle tanımlar;

"Osmanlılar masayı bilmiyorlardı; yere çoğunlukla deriden yapılan ve sofra denilen bir tepsi koyup onun üstünde yemek yerlerdi; böyle yer sofrası olarak tahta ya da madeni siniler de kullanılırdı. (...) Sofra sözcüğü bugün hala yemek sözcüğü yerine kullanılmaktadır, örneğin konuklar masaya değil, sofraya buyur edilir."18

Uzun süre Hoca Ali Rıza'nın sanılan aslında üçüncü kuşak ressamlar içinde yer alan ölüm tarihini bulamadığımız, ancak 1875 doğumlu olduğu bilinen asker kökenli Ali Rıza Toroslu'ya ait olduğu anlaşılan Ifftar Sofrası resmi (F.3) Suraiya Faroqhi'nin tanımının görsel ifadesi gibidir. Resim loş bir odada yere serilmiş halılar ve postlarla bir iç mekân betimidir. ${ }^{19}$ Resmin

18 Suraiya Faroqhi, Osmanlı Kültürü ve Gündelik Yaşam Ortaçağdan Yirminci Yüzyıla, (Çev. Elif Kılıç), Tarih Vakfı Yayınları, İstanbul 2005, s. 175.

19 Deniz Çalışır, “İftar Sofrası: Sanatçısı Kim?”, Sanat Tarihi Yıllığı, Sayı: XVII, İstanbul Üniversitesi Edebiyat 
betimlendiği yer belirsizdir. Ancak sofranın oturma odasında kurulduğu dikkate alındığında burası da günlük hayatın geçtiği oturma odası olmalıdır. Resim bir hasır tabure ve üzerindeki geniş sinide bulunan, dumanı tüten bir çorba kâsesi, simit, dört tahta kaşık, bir bıçak, zeytin, peynir, reçel kâseleri, büyük bir somun ekmek ile limon ve domatesten oluşan bir yemek sahnesidir. Sofra, son derece mütevazı, biraz sonra oruçlarını açacak Müslüman bir ailenin sofrasıdır. O nedenle sıradan bir "Natürmort" olarak nitelemeden öte anlamlara sahiptir. Resimde insanları göremeyiz, ama sanki oradadırlar. Belki camdan şerefelerin yanmasını ya da iftar topunun patlamasını beklerler, belki de dua ediyorlardır. Ressam kişisel/özel alana hiç girmeyecek, onu sergilemeyecek ve bu alanın mahremiyetini hep koruyacaktır. ${ }^{20}$ Sininin hemen yanındaki üç ayaklı sehpanın üzerinde tütün sarmaya yarayan malzemeler bulunur. Evin erkeğinin iftardan sonra bu tütünü saracağına vurgu yapar ve resmin samimi havasını artırır. ${ }^{21}$

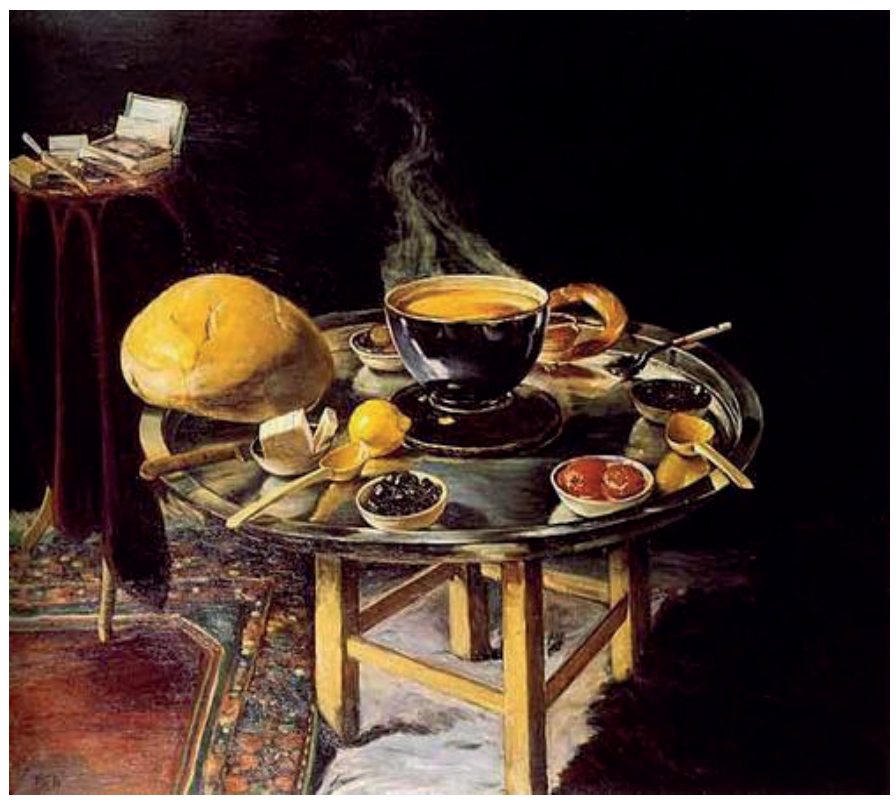

F. 3: Ali Rıza Toroslu, Iftar Sofrası, 1919, Tuval üzerine yağlıboya, 79x98 cm, Yapı Kredi koleksiyonu, (Haz. Veysel Uğurlu), Ressam Hoca Ali Rıza 1858-1930, Yapı Kredi Yayınları, İstanbul 2013, s. 77)

Yemek sofrasına dair betimlerin bir iftar sofrası ile başlamış olması kuşkusuz ki şaşırtıcı değildir. Nitekim Türk mutfağındaki yemeklerin en önemlisi iftar sofrası için hazırlanır. Ramazan

Fakültesi Sanat Tarihi Araştırma Merkezi, İstanbul 2011 [Baskı Tarihi: 2012], s.27-39 [Hoca Ali Rıza'nın resmi olarak bilinen Iftar Sofrası adlı resmin Deniz Çalışır tarafından Ali Rıza Toroslu’ya ait olduğu anlaşılmıştır.]

20 Canan Beykal, "Hoca Ali Rıza", Sanat Dünyamız, Kış, Sayı 97, İstanbul 2006, s. 23-24.

21 İlkay Canan Okkalı, Türk Resminde İç Mekân Resimleri (1880-1950'li Yıllar), İstanbul Üniversitesi, Sosyal Bilimler Enstitüsü, Sanat Tarihi Anabilim Dalı Doktora Tezi, İstanbul 2014, s.149-150. 
gelmeden yapılan alışveriş hazırlıkların temelini oluştururken, sahurlarda genellikle hafif yenmesi âdetse de Osmanlı döneminin vazgeçilmez yiyeceği pilavın sahurda da kendisine yer bulduğu görülür. Türk edebiyatının önemli ismi Refik Halid Karay iftar ve sahur sofralarını şöyle anlatır:

"Peki, yemekler nelerden ibaretti? Görenek olarak şu liste kabul olunmuştu: Önce iftariye... Varlıklı veya gösteriş meraklısı konaklarda havyar ezmesi, balık yumurtası dâhil çerezlerle reçellerin enva1 ve pide ile simit. Hurma ile zeytin şarttı zira orucu daha ziyade kudsî mahiyet taşıyan o iki meyva ile açmak âdetti; Zemzem'i tercih eden de bulunurdu. İftar tepsisi kalkınca çorba gelirdi; çorbayı yumurta takip ederdi. Peynirli veya soğanlı yahut da pastırmalı yumurta konmıyan sofra yoktu. Bundan sonra gelen bir et yemeği, arkasından börektir. Börek kalkınca herhangi bir sebze. Sebze gidince pilâv; pilav üstüne tatlı... Tam yedi çeşit yemek! Ramazanlarda zeytinyağlı ve balık nedense yenmez, iftar sofrasında yer almazdı. Yemeği yiyen kahvesini içtikten sonra veda edip gitmekte serbestti. Kalmak ve sohbet etmek isteyenlere limonatalar, şuruplar, şerbetler sunmak da usuldendi."’22

"Bu yemekler hafifinden seçilirdi. Evvelâ "sövüş"; ince ince kesilmiş, ortaları pembemsi, etrafı bembeyaz çerçeveli, yüze gülen buz gibi soğuk etlere bir nebze iltifat edildikten sonra pirinçli ıspanak, ebegömeçli Amasya bamyası nev'inden yumuşak, yumuşatıcı, sulu bir sebze yenilmesi mutaddi. Arkasından et veya tavuk suyuna beyaz pilav yahut beyaz peynirli makarna gelirdi. Sonuncu yemek üzüm veya uryani eriği hoşafıydı. Kaba sayılan kara erik hoşafiyle kayısı pestili ezmesi 'Koğuş' yani uşak, arabacı, seyis, bahçıvan gibi erkek hizmetkârlar sofrasına çıkard1." ${ }^{\prime 3}$

Karay'ın iftar ve sahur betimlerinde geçen yemekler Türk mutfağında yıllar yılı sevilerek tüketilen yemekler arasında yer alır. En çok da yumurta yemekleri. Özellikle soğanlı yumurtanın saray mutfağında ayrı bir yeri vardır. Sultan Abdülmecid'ten başlayarak her yıl Ramazan'ın on beşinde Topkapı Sarayı'nda Hırka-i Şerif ziyaretinde, padişaha özel iftar yemekleri hazırlanır. $\mathrm{Bu}$ yemekleri pişiren Enderun efendileri arasında özellikle en güzel soğanlı yumurta yapma rekabeti vardı. Eğer padişah iftar yemeklerinden tadarken soğanlı yumurtayı beğenirse bunu hazırlayan Enderun efendisini kendisine kilercibaşı seçeceği için bu yemeğin hazırlanması çok önemlidir. Soğanın yağı yanmadan ateşte devamlı karıştırılarak pembeleşinceye kadar pişirilmesi ve daha sonra yumurtaların ilavesiyle yaklaşık 3-3,5 saat sürmesi gereklidir. ${ }^{24}$ Karay’ın sözünü ettiği makarna ise geç dönemde Osmanlı mutfağına girmiştir ve 19. yüzyılın yemek kitaplarında makaronya olarak geçer. Pilav ve çorbalarsa her dönem Ramazan sofralarının vazgeçilmezleridir. Mutfağın baş yemekleri olan çorba, pilav ve etler yaşam şartları değişen Osmanlı mutfağında 19. yüzyılda da önemini korumaya devam edecektir. ${ }^{25}$ Farklı dönemlerde

22 Refik Halid Karay, "Eski Kış Ramazanlarında Hararet Bastıran Bir Şerbet”, Mutfak Zevkinin Son Günleri, (Haz. Tuncay Birkan), İnk1lâp Yay., İstanbul 2014, s.84.

23 Refik Halid Karay, “Sahur Sofrasında Lokmalar Ağzımızda Büyürdü”, Mutfak Zevkinin Son Günleri, (Haz. Tuncay Birkan), İnk1lâp Yay., İstanbul 2014, s. 85.

24 Artun Ünsal, Osmanlı Mutfağı, Yemek Kitabı, (Haz. M. Sabri Koz,), Kitabevi Yayınları, 2008, İstanbul s. 136.

25 15. yüzyıla ve 19. yüzyıla ait yemek kitaplarında yer alan reçeteler bu konuya verilecek referanslardır. Muhammed bin Mahmûd Şirvanî, 15. Yüzyıl Osmanlı Mutfağı,, (Der. Mustafa Argunşah, Müjgan Çakır), Risale Yayınları, 
Osmanlı’yı ziyaret eden seyyahlarda mutfak konusuna değinmeden geçmezler, nitekim 16. yüzyılda Osmanlı’ya gelen Dernschwam bu dönemin yemeklerinden şöyle söz eder.

“...Başyemekleri çorbadır. Önce pirinç çorbası içilir. Koyun etinin suyundan da çorba yaparlar. Çorbaya limon suyu veya sirke dökerler, biraz da karabiber koyarlar böylece ortaya koyu bir çorba çıkar. Bundan sonra koyun etini küçük küçük doğrarlar. Arasına da soğan koyarlar ve kuru ateşte pişirirler. Pirinci önce suda haşlar sonra yağda kızartırlar. Buna pilav derler. Tabaklar silme doldurulur, üzerine yağda kızartılmış badem serpiştirilir. Yemeklerden sonra meyve verilir. Koyun etinden yapılan çorbanın içine taze bulgurda konulur. Bu çorbaya bulgur çorbası derler. ...her türlü eti tuzla pişirip çorbanın içine koyarlar. Tavuk etini de piştikten sonra parçalayıp pirinç çorbasının içine koyar ve sofraya getirirken üzerine maydanoz koyar, tarçın doldururlar." 26

16 ve 17. yüzyıllarda artık Osmanlı Devleti’nin sınırları genişlemiştir. Gerek saray aşçılarının deneyimlerinin artması gerek fethedilen yeni yerlerin mutfaklarının katkısı pişirilen yemek çeşitlerini çoğaltmış pişirme şekillerini rafine hale getirmiştir. Doğu'dan ve Batı'dan gelen çok çeşitli gıda maddeleri, gittikçe artan ziyafetler ve konuk ağırlamaları hep değişik ve beğenilecek yemek sunma çabalarını hızlandırmış, sonunda Osmanlı saray mutfağının kalitesi yükseldiği gibi üretim kapasitesi de günde beş bin, bayramlarda ise on bin kişiyi doyurmaya yetmiştir. Bir süre sonra saray mutfağının yükselişi toplumun alt kesimine de yansıyacak ve toplumun genelinin damak tadında değişimler başlayacaktır.

Batılı alafranga yaşam tarzına yöneliş seçkin kesimlerin adeta tutkusu haline gelir. Ne var ki alaturka yaşam tarzı genelde hâlâ egemendir. Saraylarda, konaklarda yemek yeme alışkanlıkları ve tarzı hemen hemen aynıdır. Yer sofralarında kadın ve erkeklerin birbirlerinden ayrı olarak yemesi, toplum halinde yaşamanın önemli bir göstergesidir. Nitekim Sâmiha Ayverdi, İbrâhim Efendi Konă̆g’'nda bir 19. yüzyıl konağındaki iftar sofrasını şöyle betimler.

“... İftar sofralarının en câzip tarafları şüphesiz ki iftarlıklardı. Küçük küçük kahvaltı tabakları içinde renk renk, çeşit çeşit reçeller, türlü türlü peynirler, zeytinler, sucuklar, pastırmalar, susamlı susamsız simitler, ramazan sofrasının değişmez çizgilerindendi. Çerez faslı bittikten sonra iftarlıklar toplanır, keyfe göre bir veya birkaç türlü çorbadan, isteyen istediğini alır, bu iş de tamam olduktan sonra kıymalı ve pastırmalı yumurta tepsisi ortaya gelirdi. Fakat yalnız iftarlıkla bile doyulabilecekken, yumurtadan sonra etler, sebzeler, börek, tatlı ve meyveler, sırasıyla konup kalkardı. Oldu olası mutfağı ile damağı arasında sıkı bir münâsebet kurmuş olan bu ecdat mîrâsı boğaz düşkünlüğü, bilhassa ramazan aylarında alabildiğine at koşturur, mevsimine göre değişen oruç saatlerinin açlığını, nakıl gibi donattığı sofralarla karşılardı."27

İstanbul 2018; Ahmed Cavid, Tercüme-i Kenzü'l-İştiha 15.Yüzyıldan Bir Mutfak Sözlüğü, (Der. Priscilla Mary Işın, Seyit Ali Kahraman), Kitap Yayınevi, İstanbul 2006; Mehmed Kâmil, Melceü’t Tabbâhîn Aşçıların Sığınağı, (Günay Kut, Turgut Kut), Türkiye Yazma Eserler Kurumu Başkanlığı, İstanbul 2015; Ayşe Fahriye, Ev Kadını, (Turgut Kut), Çiya Yayınları, İstanbul 2018.

26 Hans Dernschwam, İstanbul ve Anadolu’ya Seyahat Günlüğü, Kültür ve Turizm Bakanlığı, Ankara 1987, s. 170.

27 Sâmiha Ayverdi, İbrâhim Efendi Konağı, Kubbealtı, İstanbul 2009, s. 104. 
İstanbul'un konak hayatı İbrâhim Efendi Konağı'nda olduğu gibi her ne kadar geleneksel çizgisini korumaya devam etse de 19. yüzyıl Osmanlı İmparatorluğu için pek çok "ilk" barındırır. Sultan II. Mahmud'un tahta geçişiyle başlayan süreçte ilk kez çatal ve bıçak kullanılacak, masa düzeninde yemek yenilmeye başlanacaktır. Kuşkusuz ki yeni bir saray yapısının da inşası ile Osmanlı için yeni yaşam tarzını da gündeme getirecektir. ${ }^{28}$ Leyla Saz, Haremin İç Yüzü adlı çalışmasında eski Çırağan Sarayı'nda geçirdiği günleri anlatır ve sarayda alafranga usulü çatal ve bıçakla yeme usulünün 1860'lardan sonra yaygınlaşmış olduğunu belirtir. ${ }^{29}$

Yaşanan mekânların değişmesi, yeni adetleri de beraberinde getirir: Oturmak, uyumak, yemek eylemleri biçim değiştirmeye başlar. Yüzyıllardır oturmak için sedir ve seki, yemek için tabla, eşya depolamak için yüklük kullanan Osmanlı, yeni yaşam mekânlarında sedirden sandalyeye, sekiden kanepeye, tabladan masaya geçiş yapacaktır. Taşınabilen koltuk, sandalye, dolap, masa gibi kullanım eşyalarının mimari ile bütünleşen elemanların yerini alması farklı işlevdeki mekânları da gündeme taşıyacaktır. Daha önce tanımlanmamış mekânlar olan yemek odası, yatak odası gibi önceden işlevlendirilmiş mekânlar ev içlerinde yerlerini alacaktır. Nitekim 1856'da kullanıma açılan Dolmabahçe Sarayı, dikey düzlemde yükselen mimarisi, katlara hiyerarşik olarak dağılmış oda ve salonları ile bu anlamda değişimleri başlatan ilk simge yapı olur. Geniş pencerelerin ve kapıların hâkim olduğu yeni mimari kurgu geleneksel düzlemdeki sedirin yerine Batı kaynaklı mobilyayı ihtiyaç nesnesi haline getirirken siyasi yapıdaki her değişim aşağıya doğru yansıyacaktır. ${ }^{30}$

Dolmabahçe Sarayı'nda başlayan yeni tanımlanmış mekânlar Beylerbeyi ve Yıldız saraylarında da devam edecektir. Yıldız Sarayı'nın bölümlerinden biri olan Şale'de Alman İmparatoru II. Wilhelm için köşk yeniden düzenlenir ve 12 numaralı odası yemek ve kahvaltı salonu haline getirilir. ${ }^{31}$ Artık sofra tanımlanan mekânların arasındadır ve yer sofrası yerini masa sandalye düzenine bırakmıştır. Söz konusu odada Sultan II. Abdülhamid tarafından Alman İmparatoru onuruna verilen ziyafet, önce fotoğraflanır ${ }^{32}$ ardından ölüm tarihi bilinmese de 1868 doğumlu olduğu bilinen Darüşşafakalı ressam Şefik tarafından tuvale aktarılır.

28 Demet Coşansel, “19. Yüzyılda Osmanlı Sarayı’nda Mutfak Gelenekleri ve Sofra Düzeni”, 150 Yılın Sessiz Tanıkları Saray Porselenlerinden İzler, (Haz. İ. Baytar), Milli Saraylar Yayınları, İstanbul 2007, s. 31.

29 Leyla Saz, Anılar 19. Yüzyılda Saray Haremi, Cumhuriyet Kitapları, İstanbul 2010, s. 110.

30 İlona, Baytar,“19. Yüzyıl Osmanlı Saraylarına Ait Dekorasyon Katalogları”, Sanat Tarihi Yılığı, Sayı:24, İstanbul 2016, s. 2-3.

31 MSA. d. 3842 Hazine-i Hassa İnşaat ve Tamirat Haftalık Amele Jurnalleri, sene: 1308, sira no: 1; Feryal İrez, "Belgeler Işı̆̆̆ında Son Alman İmparatoru II. Wilhelm’i Konuk Eden Bir Kasr-I Hümâyûn; Şale", İki Dost Hükümdar Sultan II. Abdülhamid-Kaiser II. Wilhelm, (Haz. İlona Baytar), Milli Saraylar Yayınları, İstanbul 2009, s. 51.

32 Yıldız Albümleri, İstanbul Üniversitesi Nadir Eserler Kütüphanesi, 90614-0010. Feryal İrez,a.g.m., s.53. 


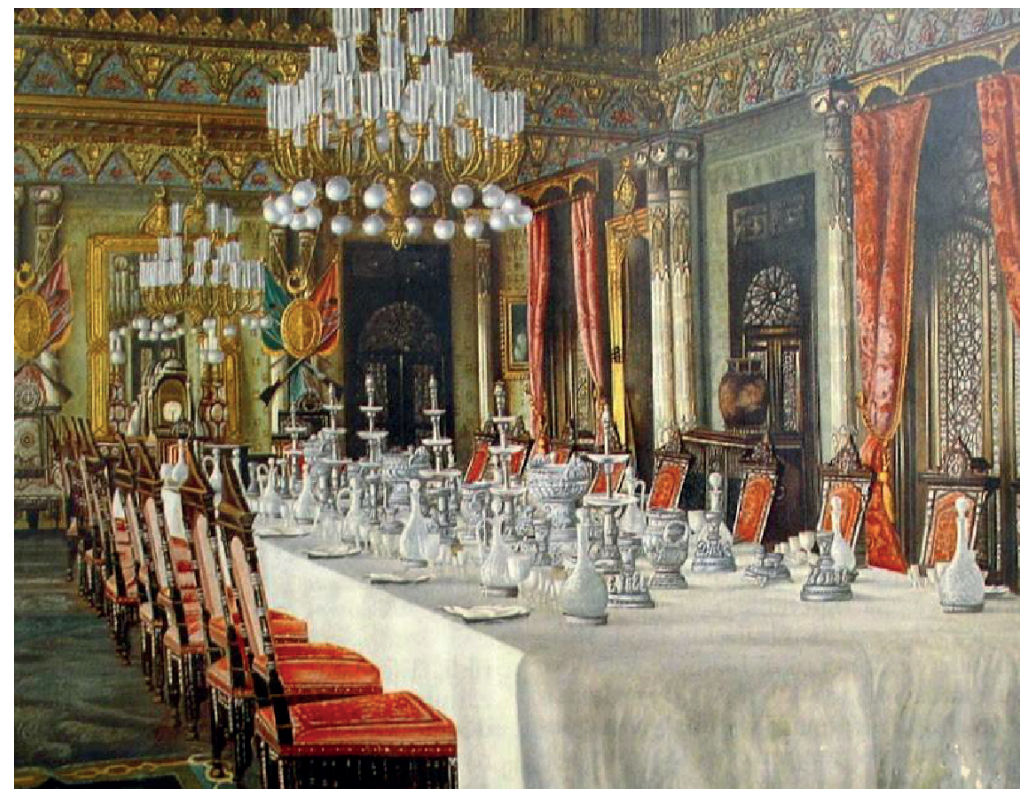

F. 4: Şefik, Yıldız Sarayı Şale Kasr-ı Hümayunu Yemek Salonu, 1891, Tuval üzerine yağlıboya, $73 \times 91 \mathrm{~cm}$, Mimar Sinan Üniversitesi Resim ve Heykel Müzesi Koleksiyonu (Sezer

Tansuğ, Çağdaş Türk Sanatı, (8.bs.), Remzi Kitabevi, İstanbul 2008, s.85)

Darüşşafakalı Şefik'in 1891'de yaptığı Yıldız Sarayı Şale Kasr-ı Hümâyunu Yemek Salonu adlı çalışmasında (F.4) karşılıklı sekizer olmak üzere toplam on altı servisin davete hazır bir şekilde düzenlendiği bir yemek masası ve bu masanın içinde bulunduğu odanın betimlenmesidir. Yapıt, fotoğraftan çalışıldığı için masanın ön tarafındaki eşyalarda bazı perspektif hataları olmakla birlikte resmin bütününde son derece gerçekçi, ama bir o kadar da anın, salonun, masanın donmuş bir görüntüsüdür. Sezer Tansuğ'un Abdullah Biraderler'in çektiği bir fotoğraf albümünde yaptığı incelemeler sonucu söz konusu resimlerin tümüyle fotoğraf modellerine dayandı̆̆ 1 kesinleşmiştir. ${ }^{33}$

19. yüzyılın ikinci yarısına gelindiğinde yeme içme alışkanlıklarındaki kültürel evrim kendini iyice hissettirir. Fasulye, domates, patates, mısır, sakız kabağı, yer elması, taze biber gibi Amerikan kökenli sebzelerin ülkede ekiminin yaygınlaşmasının bu değişimimeki payı büyüktür. Yine Amerika kökenli Hint tavuğu adı verilen hindinin İstanbul'da da yetiştirilmesi, İstanbul mutfağına yeni lezzetler kazandırması kaçınılmazdır. Geleneksel damak tadı ve pişirme yöntemlerinin bu yeni ürünlere uyarlanmasıyla, İstanbul mutfağı daha da zenginleşir. ${ }^{34}$ Toplumun üst kesiminde başlayan yeni mekânlar ile yeni sofra düzeni ve yeni lezzetler kısa

33 Sezer Tansuğ, "Resim Sanatımızda Ortaya Çıkan Yeni Bir Gerçek: 19. Yüzyıl Sonu Foto-Yorumcuları", Çağdaş Türk Sanatına Temel Yaklaşımlar, (1.bs.), Bilgi Yayınevi, İstanbul 1997, s.41.

34 Artun Ünsal-Beyhan Gence Ünsal, İstanbul'un Lezzet Tarihi, NTV Yayınları, İstanbul 2011, s. 111. 
bir süre sonra toplumun geneline yayılır. Dönemin yazın dünyasında üzerinde durulan kimi zaman da hicivle değinilen konular arasına girer. Nitekim değişim, sadece damak tadında değil masa düzeninde de olur ve el ile yemek yemek yerini çatal ve bıçağa bırakmaya başlar. Hüseyin Rahmi Şıpsevdi'de çatal ve bıçak kullanımına şöyle değinir;

"Ne yediğimi biliyorum, ne içtiğimi. Hepsi görünüşte Müslüman ama yaşamları bizimkine uymuyor. Yemeği elle yemiyorlar. Çatal dedikleri o zıkkımı kullanıyorlar. Körolasıcayı kaç defa damağıma batırdım, ağzım şişti. Azize Hanım, üzgün üzgün gözlerini süzüp: -Dünyada o zıkkımla yemek yiyenlere yarın ahrette zebaniler uçları sivri kızgın çatallarla yemek verecekler. Aman Rabbim acımana sığındım. Allah'ın verdiği parmaklar dururken demir parçalarılyla yemek yenir mi?"’35

Refik Halid Karay'ın romanları yemek ve sofra betimlemesi açısından bolca malzemeye sahiptir. Yazarın İstanbul'un Bir Yüzü adlı romanında İsmet, Kâni ile olan ilişkisi etrafında II. Meşrutiyet dönemi zenginlerini geçmişleriyle birlikte anlatır. Tanıdığı eski ve yeni simalar özellikle sofra etrafında kimliklerini, zenginliklerini, görgü ve görgüsüzlüklerini belli ederler. Konağın eleştirilen kişilerinin başında damat İshak Bey vardır. İshak Bey’in “çapacul” ve hödük" olarak tanımlanması sofradaki davranışları dolayısıyla pekiştirilir, böylece yemek gibi temel bir eylemi ve sofra gibi en önemli sosyalleşme alanlarından birini layıkıyla yerine getiremeyen İshak Bey’in görgüsüz biri olduğu kuvvetle vurgulanır. ${ }^{36}$

"Asıl görülecek, seyredilecek hali yemekteydi. O ne acemice, o ne bayağı oturuştu! Daha çatal ve bıçağ tutmasına eli yatmamıştı; iki de bir düşürürdü; masadan dört karış ötede, yan piri durur, havlusunun bir ucunu tabağına sıkıştırır, öbür ucunu gırtlağından berber önlüğü gibi sıkıca geçirirdi. İçine ekmek doğrayarak hohluya üfüre şapır şapır, kaşık dolusu bir çorba içişi vardı, bütün sofra halkının sinirlerini oynatırdı. Döke saça, acele acele, lüzumsuz bir iş yapar, bir angarya savar gibi yemeği herkesten evvel bitirir; kocaman bir 'Elhamdülillah!' çektikten sonra yılan gibi kayarak yan kapıdan odasına çekilirdi." ${ }^{37}$

Karay, $\ddot{U} c ̧$ Nesil $\ddot{U} c ̧$ Hayat'ta ise ayrıca şöyle değinir;

"Yeni yetişen neslin mensupları şayet sofrada bu gibi mutaassıp biri bulunur, parmaklarıyla yerse iğrenirler, 'Ay aman, midem bulandı... O kadın (veya erkek) varsa bir daha yemeğe gelirse ben ayrı yerim, sofraya inmem!' derlerdi. Beceriksizliklerinden dolayı çatala bir türlü eli yatmayanlar bütün yemekler için kaşık kullanmak suretiyle iğrenç olmamaya çalıştıkları gibi bir kısım küçük aileler de çatalla yemek yenilmesi mutat olan büyük evlere gitmeleri icap edince yolda söylenirlerdi. 'O cânım yemekleri şöyle oturup da elimizle rahat rahat yiyemeyeceğiz ki... Vallahi hiç birinin lezzetini alamıyoruz!' Çatal bunların elinde külçe demir kadar ağırlaşırdı, düşürüp önlerindeki tabağı kırma korkusuyla da büsbütün acemileşirler, azap çekerlerdi" ${ }^{38}$

35 Hüseyin Rahmi Gürpınar, Şıpsevdi, Özgür Yay., 11.bs., İstanbul 2014.

36 Nihan Abir, Siniden Masaya: Türk Romanında Sofra, Mimar Sinan Güzel Sanatlar Üniversitesi, Sosyal Bilimler Enstitüsü, Türk Dili ve Edebiyatı Anabilim Dalı Yeni Türk Edebiyatı Programı Doktora Tezi, İstanbul 2018, s. 43.

37 Refik Halid Karay, İstanbul'un Bir Yüzü, İnkılâp Yay., 8. Bs., İstanbul 2017, s. 58.

38 Refik Halid Karay, Üç Nesil Üç Hayat, İnkılap Kitabevi, İstanbul 2010. 
Refik Halid Karay'ın romanlarında sadece Batı medeniyetinin değil özellikle mutfak ve yemek konusunda Osmanlı Devleti'nin âdetleri de ön plandadır. Bu eserlerde eğer aile köklü ya da görgülü ise çoğunlukla iyi bir aşçıya, sağlam bir mutfak zevkine sahiptir. Anlatıcının bunlara sempati ile yaklaştığı da rahatlıkla söylenebilir. Sonradan görme ya da züppeleşmiş tiplerin ise aşçıları ya çok kötüdür ya da bu kişiler sürekli dışarıda yemeyi tercih ederler. ${ }^{39}$ Osmanlı' da yemek kültüründe iki öğün yemek yenirdi; kuşluk vakti ve akşam. Kahvaltı Tanzimat'la birlikte zengin aileler arasında yayılmaya başlar. Refik Halid'in Ekmek Elden Su Gölden romanında da kahvaltıya verilen önem şu sözlerle dile getirilir: "İnsanlar servet derecelerine bakmadan uygarlık düzeylerinin yüksekliği ve uygar bir aile olmaları oranınca sabah kahvaltısına değer verirler ve sofra başında iç açıcı bir "iç yaşama" tablosu meydana getirirler." 40

Romanlarda sıklıkla ele alınmasına karşın Türk resminde henüz yeni yeni iç mekânı ve sofra başında aileleri gösteren resimler yapılmaya başlanır. II. Meşrutiyet'in ilanı ve getirdiği görece özgür ortam, sanatçıları da konu seçiminde daha serbest kılmış olmalıdır. Bu kuşağın en önemli sanatçı grubu kuşkusuz 1914 Kuşağı'dır. 20. yüzyılın başında Paris'e giden ve Birinci Dünya Savaşı ile yurda dönen bu sanatçıların yapıtları toplumun değişiminin en iyi yansıdığg çalışmalar arasında yer alırlar. Nitekim Feyhaman Duran'ın İç Mekân çalışmasında (F.5) samimi bir ev içi betimlemesi görülür. Sanatçı, üzerinde çeşitli yiyeceklerle dolu bir masa, iki sandalye ve arkalarındaki duvarda yer alan büyük bir manzara tablosunun olduğu köşeyi betimler. Masanın üzerindeki iki servis, yemekten önceki bir anın kompozisyonu olduğunu hissettirir. ${ }^{41}$ Söz konusu resim incelendiğinde yemek için ayrılmış özel bir mekân, masa ve düzeni söz konusudur. Ancak Şefik, Ali Rıza Toroslu gibi ressamların figürsüz sofra betimleme geleneği Feyhaman'da da devam etmektedir.

39 Nihan Abir, a.g.e., s.226.

40 Refik Halid Karay, Ekmek Elden Su Gölden, İnkılâp ve Aka Yay., İstanbul 1985, s. 64.

41 Okkalı, a.g.e., s. 298-299. 


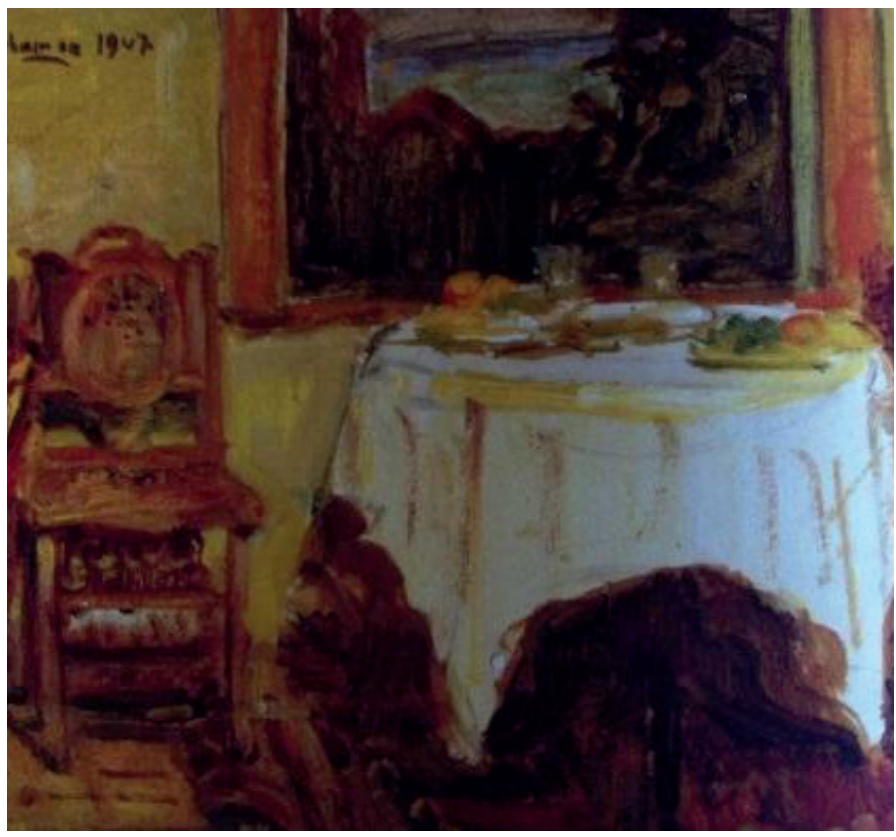

F. 5: Feyhaman Duran, İç Mekân, 1943, Karton üzerine yağlıboya, 27x19 cm, (İstanbul Üniversitesi Resim Galerisi Koleksiyonu Demirbaş No:760/2000), (Ed.V.Belgin Demirsar Arlı), T.C.İstanbul Üniversitesi Rektörlüğü Bilim ve Sanat Merkezi Resim Galerisi/ Pinakothek-Katalog/Catalogue,İstanbul Üniversitesi Rektörlüğü/Garanti Bankası, İstanbul 2004, s.172)

Bedri Rahmi Eyüboğlu (1911-1975) 42 $^{2}$ da İçi (F.6) çalışmasında masanın üzerinde yer alan yiyeceklerle birlikte bir kadını betimlemiştir. Yiyecekler çok belli belirsizdir. Tabakların olmaması, sadece meyvelerin olmasından sofra görüntüsünden ziyade çay saati olduğunu düşündürür. Kıymet Giray, Matisse'in iç mekân resimlerinin hatırı sayılır sayıda yemek kültürünü gösterdiğini vurgulayarak, bu resimde de Matisse etkisinin gözlemlendiğinden söz eder. ${ }^{43}$

42 d grubu ressamları arasında yer alan Bedri Rahmi Eyüboğlu aynı zamanda Yurt Gezileri'ne de katılmıştır. 1938'de Edirne'ye, 1942'de ise Çorum'a gitmiştir. Ayrnntılı bilgi bk. Elif Naci, “'d' Grubu”, Ankara Sanat, Yı1:8, Sayı: 88, Ağustos 1973, Ankara Ağustos 1973, s.8; Ömer Faruk Şerifoğlu, "Bedri Rahmi Eyüboğlu Yüz Yaşında", Bedri Rahmi Eyüboğlu, (Ed. Ömer Faruk Şerifoğlu), Ankara, T.C. Kültür ve Turizm Bakanlığı Yayınları, 2011, s. 12-15.

43 Kıymet Giray, Sabancı Üniversitesi Sakıp Sabancı Müzesi Resim Koleksiyonundan Seçmeler, Sabancı Üniversitesi Sakıp Sabancı Müzesi, Akbank, İstanbul 2002, s. 198. 


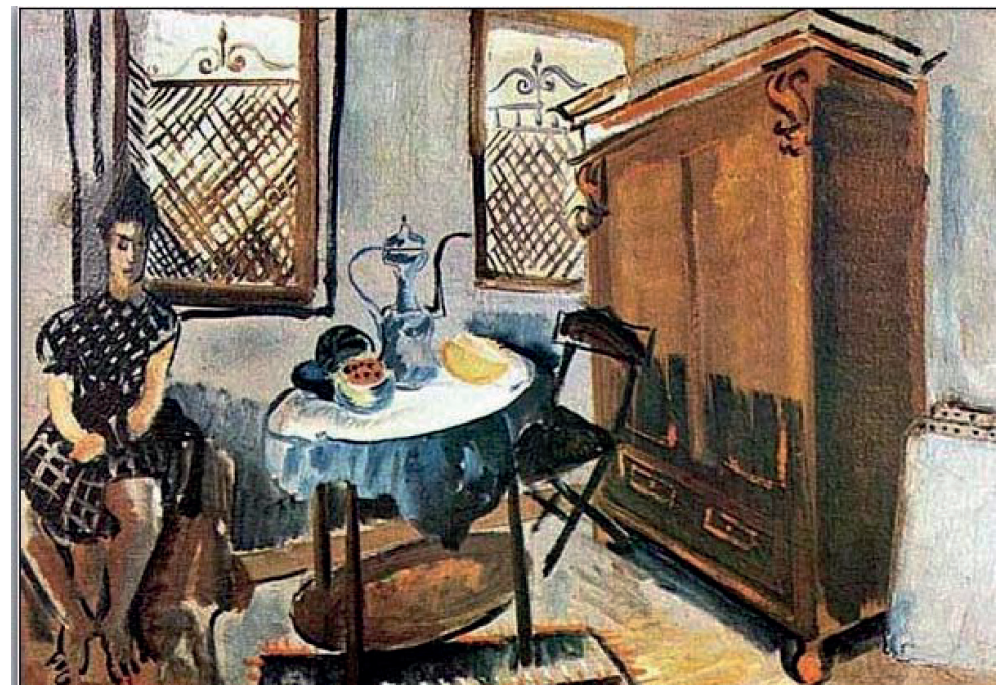

F. 6: Bedri Rahmi Eyüboğlu, Oda İçi, 1937, Tuval üzerine yağlıboya, 50x68 cm, (MSGSÜİRHM), (Ahmet Kamil Gören, "Cumhuriyet Dönemi İstanbul'unda Resim Sanat1, (Ed. Fahameddin Başar), Kültürler Başkenti İstanbul, (1.bs.), Türk Kültürüne Hizmet Vakfiİstanbul 2010 Avrupa Kültür Başkenti Ajansı, İstanbul 29.10.2010, s.690)

Sosyal statü gösteren sofralar, roman karakterlerinin toplumsal konumlarını betimledikleri gibi, maddî durumlarını göstermek için de kullanılır. Bunun yanı sıra kişinin parasal durumu çok iyi olmasa da toplumdaki yeri ve önemi onun zengin sofralarına davet edilmesine olanak tanıyabilir. Önce Yeniler Grubu ardından 1946'da Paris'e giderek resim tekniğini soyut çalışmalarla değiştiren Nejad Melih Devrim’in (1923-1995) 1940’lı yılların başında yaptığı Enteryör çalışması (F.7) sosyal statüyü sofra üzerinden anlatan bir çalışmadır. Bu resim de sofrada insanların gösterilmediği resim geleneğini devam eder. Sanatçı, hazırlanmış bir yemek masası ve yemek odasını betimler. Altı kişilik yemek masası üzerinde tabaklar, yiyecekler, çiçekler, mavi renkte porselen yemek kapları bulunur. Arkada yer alan aynalı büfenin üzerinde çiçekler, çeşitli renkte porselen vazolar ve aksesuarlar yer alır. Zengin süslemeli halı ve gösterişli avize, mekânın dikkat çekici öğeleridir. Yemek masasının her iki tarafında masaya katılacak kişiler için hazır bekletilen iki adet sarı renkte sandalye de mekânın zengin görselliğine katkıda bulunur. ${ }^{44}$ 


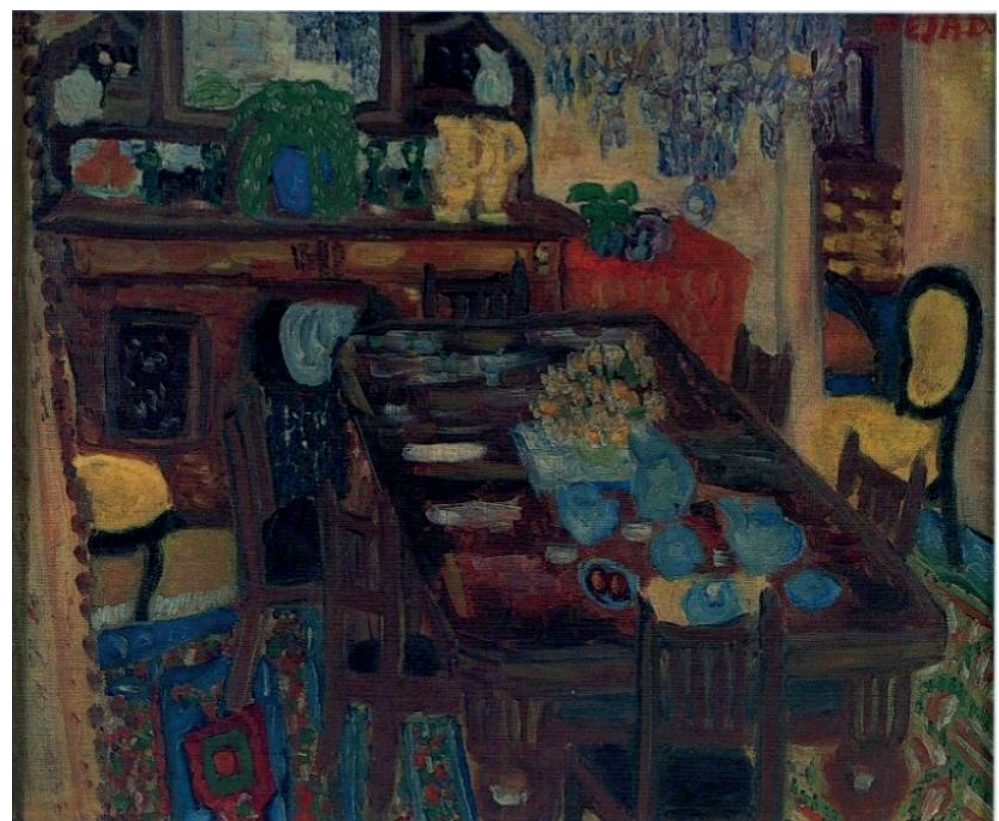

F. 7: Nejad Devrim, Enteryör, 1943, Tuval üzerine yağlıboya, 38x46 cm, (Mehveş-Selim Demiren koleksiyonu), (Ed. Cem İleri), Fahrelnisa ile Nejad: Gökkuşağında İ́ki Kuşak, İstanbul Modern Sanat Müzesi, İstanbul 2006, s. 120)

Ailenin bir araya geldiği ve sohbet edilerek paylaşımda bulunduğu sofralar, 1914 Kuşağ1 sanatçılarından sonra betimlenmesi sevilen konular arasına girer. Melahat Üren'in (1918$1969)^{45}$, Aile adlı resmi yemeğin aileyi bir araya getiren özelliğinin vurgulandığı çalışmalardan biridir (F.8) Sanatçı, sıcak aile ortamında bir masa etrafında toplanılan yemek sahnesini betimlemiştir. ${ }^{46}$ Yemekler net olarak gösterilmemiştir. Buna karşın diğer sofra resimlerinden farkı figürlerin sofra başında toplanmaları, yemeğin servis edilmesi, yemeğe uzanıp yeme gibi davranışların gösterilmiş olmasıdır ki resim bu açıdan önemlidir. Aslında resmin asıl vurgusu toplum önünde yemek yememek gibi bir tabunun getirdiği mahrem duygunun yavaş yavaş kalkmaya başladığının gösterilmesidir.

45 d Grubu ressamları arasında yer alır. İlk olarak 1935 sergisine katılır. Bk. İlkay Canan Okkalı, "Renkli Bir Yuva: Eşref Üren ve Melahat Üren'in Resimlerinde Ev", Uluslararası Geleneksel Sanatlar Sempozyumu Bildiri Kitabi 20-21 Nisan 2017, Trabzon 2017, s. 510-511. 


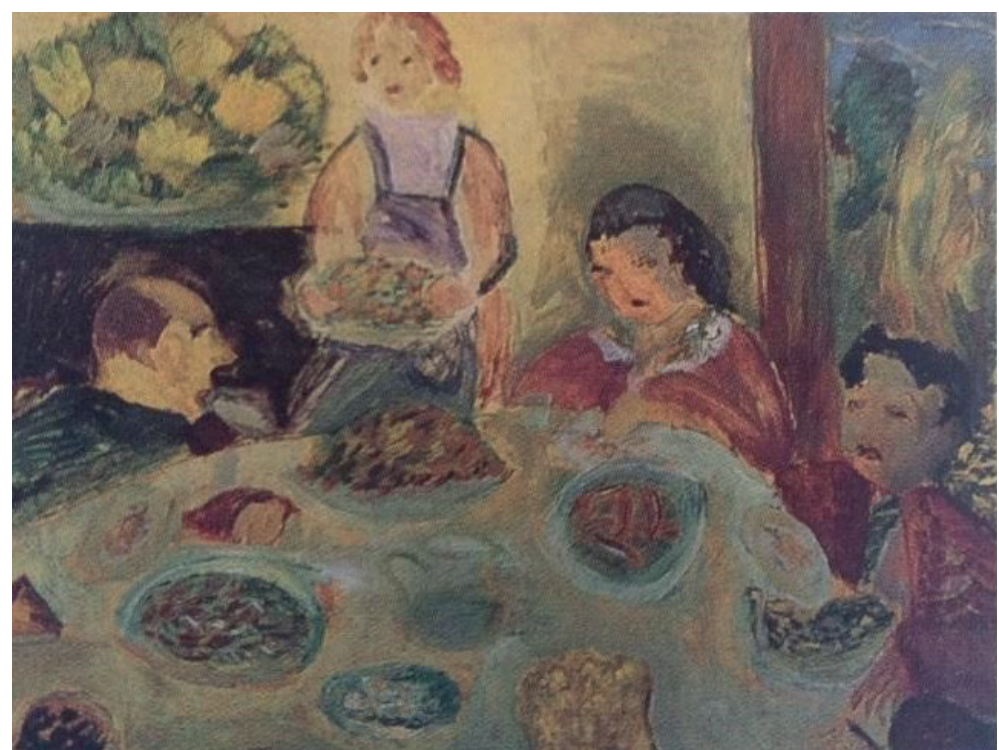

F. 8: Melahat Üren, Aile, Tuval üzerine yağlıboya, (Türkiye İş Bankası koleksiyonu), (Kıymet Giray, Türkiye İş Bankası Resim Koleksiyonu, Türkiye İş Bankası Kültür Yayınları, İstanbul (1998), s.633)

Figürlü sofralar 1950'lerde daha sık görülmeye başlanır. Eşref Üren (1897-1984) Enteryör/Sofra Hazırlı̆̆ı yapıtında, (F.9) eşi Melahat Üren'e benzeyen bir kadını yemek hazırlığı için sofra kurarken betimlemiştir. Sofra meyveler, sürahi, kesilen ekmek görüntüsü ile detaylandırılmıştır. Bu detayları, "Batı resminde karşımıza çıkan mutfak sahnelerinde önde yer alan zengin yiyeceklerle Natürmorta benzetmek yanlış olmaz. Batı resminde mutfak sahnelerinin betimlendiği çalışmalar resmi tür resmine bağlarken, Üren'in sofra hazırlayan kadın betimi de bu resmi gündelik yaşam sahnelerine bağlar." 48

471931 'de Müstakil Ressamlar ve Heyketraşlar Birliği sergisine, daha sonra d grubu sergilerine katılır, 1940'da üçüncü yurt gezisi için Yozgat'a, altıncı yurt gezisi için 1943’te Ağrı'ya gider. Bk İlkay Canan Okkalı, "Renkli Bir Yuva: Eşref Üren ve Melahat Üren'in Resimlerinde Ev”, Uluslararası Geleneksel Sanatlar Sempozyumu Bildiri Kitabi 20-21 Nisan 2017, Trabzon 2017. 


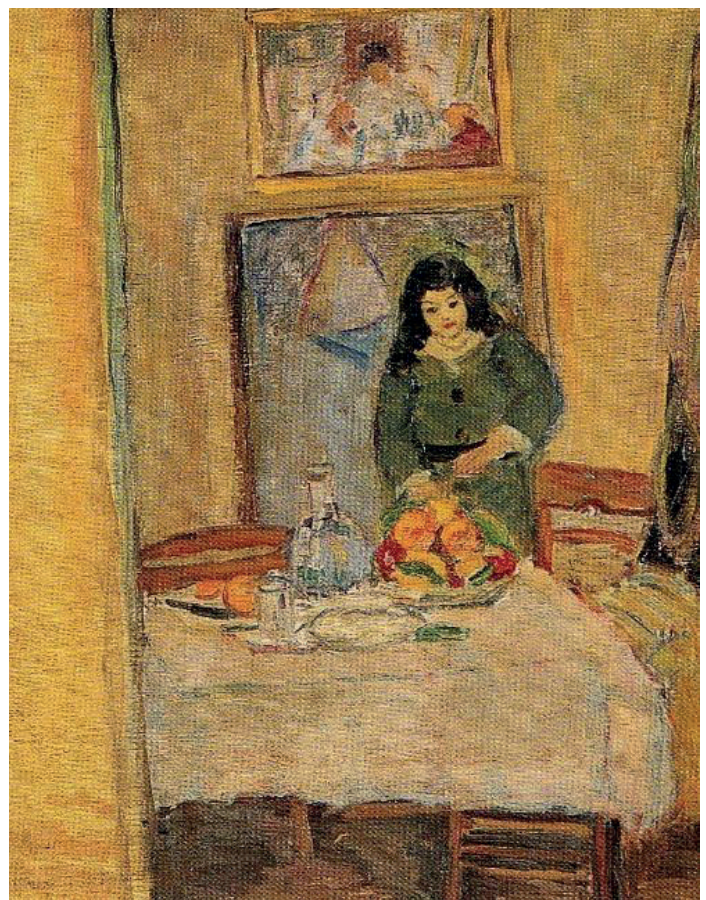

F. 9: Eşref Üren, Enteryör/Sofra Hazırlı̆̆g, 1950’ler, Tuval üzerine yağlıboya, 59x49 cm, (Türkiye İş Bankası koleksiyonu), (Kıymet Giray, Türkiye İş Bankası Resim Koleksiyonu, Türkiye İş Bankası Kültür Yayınları, İstanbul (1998), s.408)

Yemek hazırlığı ve sofra konusunu resminin teması olarak alan bir başka sanatçı da Ziya Keseroğlu'dur (1906-1973). Sanatçı, Enteryör çalışmasında (F.10) ön planda meyve tabağı ve kadın figürü yer alır. Öndeki iki madeni tabak içerisinde salkım üzüm salkımı ve iki elma, ayaklı meyve tabağında ise armut, üzüm, şeftali, elma gibi çeşitli meyveler yer alır. Resim gündelik hayatın herhangi bir anından izler taşır. Arkada büfenin üzerinde yer alan tablo-ayna, çalar saat, testi gibi dekoratif ve teknolojik malzemeler, mekânın zengin dekorasyonuna vurgu yapar. ${ }^{49}$

49 Müstakil Ressamlar ve Heykeltraşlar Birliği’nin sergilerine katılan Ziya Keseroğlu, grup dağıldıktan sonra hiçbir gruba bağlı olmadan çalışır. Okkalı, Türk Resminde İç Mekân Resimleri (1880-1950’li Yıllar), 2014, s. 518-519. 


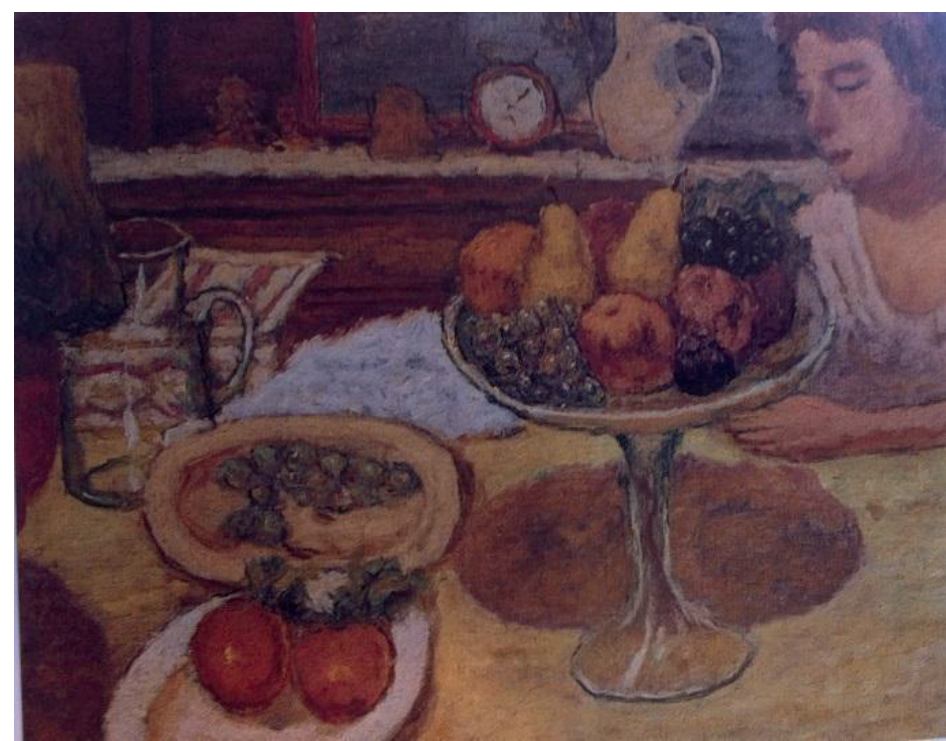

F. 10: Ziya Keseroğlu, Enteryör, Tuval üzerine yağlıboya, 50x61 cm, (MSGSÜİRHM),(Başlangıcından Bugüne Türk Resmi İçin Bir Müze Denemesi, Sanat Dünyamız, Say1:88, Yaz 2003, İstanbul 2003, s.119)

Tanzimat dönemi ile birlikte Batı mutfağıyla tanışan Türk mutfağında yenilen yemeklerle birlikte sofra düzeni de değişir ve değişimin vurgusu özellikle erken Cumhuriyet döneminden günümüz resmine kadar Türk resminde sevilerek kullanılan konular arasında yer alır. Ancak üst tabakada başlayan değişimler toplumun diğer katmanlarda aynı anda bir kırılma getirmez ve toplumsal katmanlar kendi dinamikleri doğrultusunda değişimi gerçekleştirirler. Dolayısıyla Modernleşme olgusu ile gelen yeni yemekler ve sofra düzeni şehir hayatında hızla topluma entegre olurken kırsal kesimde benimsenmesi zaman alacaktır. Cevat Dereli'nin (1900-1989) ${ }^{50}$, Ístihsal (F.11) adlı eseri yer sofrasında çeşitli yiyecekler, meyve ve su testisinin betimi ile bu olgunun iyi bir görsel verisini sunar. Cevat Dereli bu resmi 1954'te Yap1 Kredi Bankası'nın kuruluşunun 10'uncu yılı nedeniyle düzenlenen resim yarışması için yapmıştır. ${ }^{51}$ Sanatçı 1950'li yıllarda içerik olarak yöresel bir tarz, biçim olarak da lekeci bir teknik ile kendini yenilemiştir. ${ }^{52}$

50 Müstakil Ressamlar ve Heykeltraşlar Birliği’nin bir üyesi olan Cevat Dereli (1900-1989) grup dağıldıktan sonra bireysel çalışmalarında günlük yaşamın değişen alışkanlıklarından izleri, Anadolu insanını resimlerine taşımıştır. Yurt Gezilerine katılan sanatçı o yılki programa alınmasa da arkadaşı Şeref Akdik'le beraber 1938'deki ilk geziye katıldığı düşünülmektedir. 1939'da İkinci Yurt Gezisi’nde Sinop'a 1942'de beşinci gezide Gümüşhane'ye gitmiştir. Bk. İlhan Berk, Levent Çalıkoğlu, Ferit Edgü, Turan Erol, Murat Ural, Yurt Gezileri ve Yurt Resimleri, Milli Reasürans Yayınları, İstanbul, 1998, s.78.

51 Resim, afiş, müzik, folklor ve dallarındaki yarışma, Uluslararası Sanat Eleştirmenleri Derneği'nin (AICA) 5'inci Kongresi kapsamında düzenlendi. O yıllar için kongre dolayısıyla İstanbul'a gelen Paul Fierens, Lionelle Venturi ve Herbert Read gibi sanat eleştirmenleri resim yarışmasında seçici kurulda yer alırlar. Yarışmada birinciliği Aliye Berger almıştır.

52 Tatlic1, a.g.e., s.219. 


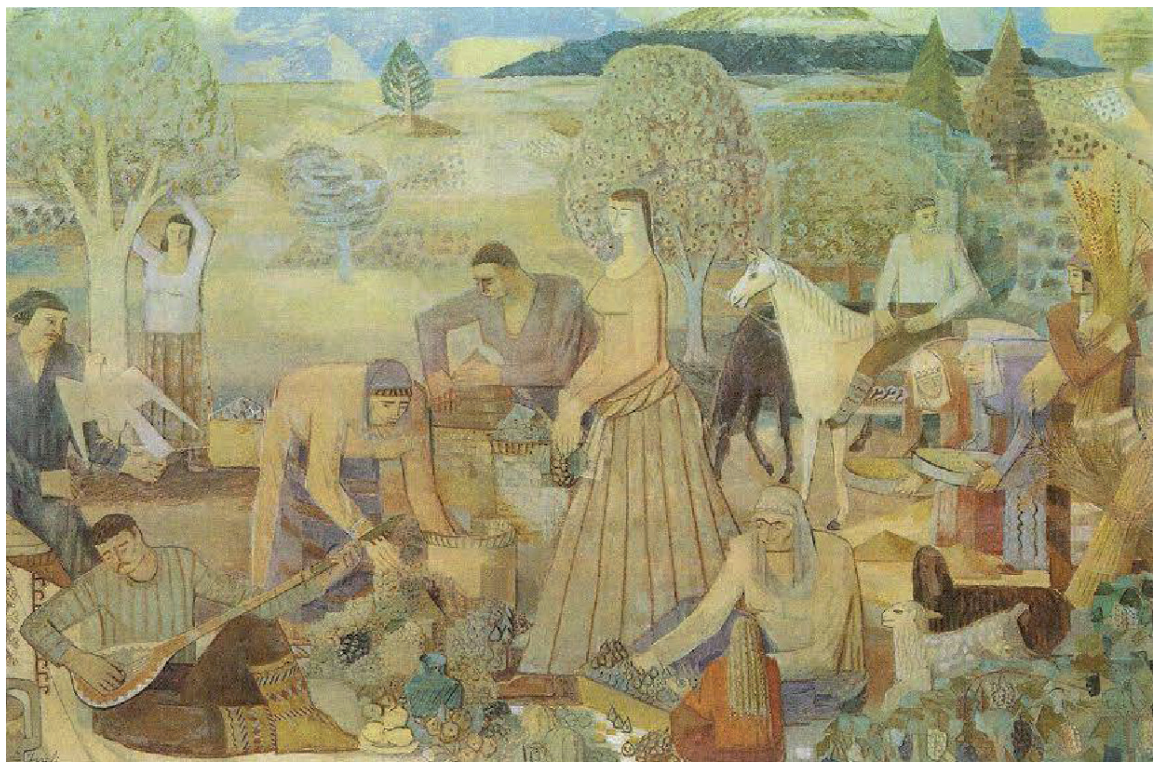

F. 11: Cevat Dereli, İstihsal, 1954, Tuval üzerine yağlıboya, 201x305 cm, İstanbul Resim Heykel Müzesi Koleksiyonu. (Haz. Özge Açıkkol ), Cevat Dereli, Yapı Kredi Kültür Sanat Yayıncılık, İstanbul, 2000, s. 109)

Ressam Turgut Zaim'de (1906-1974) ${ }^{53}$ Yörükler Köyü resminde (F.12) kırsal yaşamı idealize eden anlatımla bir sofra resmi betimler. Resme hâkim olan geleneksel sini düzenindeki yer sofrasıdır. Giysi ve kadın başlıklarında, testi, kazan, kaşık, sofra, tezgâh, heybe, çorap, çuval, kuşak vb. gibi köylülerin günlük eşyalarında da izlenebilir ${ }^{54}$

53 Müstakil Ressamlar ve Heykeltraşlar Birliği ardından 27 Aralık 1934'de dördüncü sergiden itibaren d Grubu sergilerinde yer alan Turgut Zaim (1906-1974) 1932 yılından başlayarak Anadolu’yu gezer, Yörüklerin ve Avşarlar'ın yaşantılarıyla yakından ilgilenir. Nitekim sanatçının üslubu da bu yıllarda biçimlenmeye başlar. Yurt Gezileri kapsamında 1939'da ikinci yurt gezisinde Kayseri’ye 1942'de beşinci yurt gezisinde Kırşehir'e gider. Bk. Elif Naci, a.g.e., s. 8.

54 Sezer Tansuğ, Beş Gerçekçi Türk Ressamı, Gelişim Yayınları, İstanbul 1976, s. 16. 


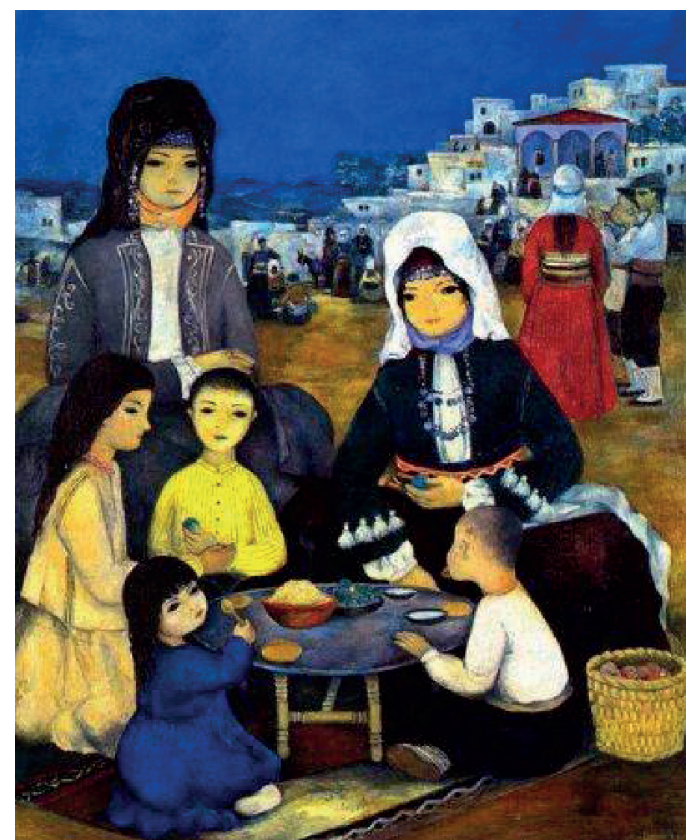

F. 12: Turgut Zaim, Yörükler Köyü, Tuval üzerine yağlıboya. 117,5x99,5cm, Ankara Resim Heykel Müzesi. (Gizem Tatlıc1, Görsel Belleğin İzinde Türk Resminde Yemek Kültürü, Işık Üniversitesi Sosyal Bilimler Enstitüsü Sanat Bilimi Programı (Yayımlanmamış) Doktora Tezi, İstanbul 2018, s.231).

Özellikle Yurt Gezileri kapsamında ressamların Anadolu’nun çeşitli yerlerine giderek köy yaşantısını, Anadolu insanını resmetmeleri ve bu topraklardaki sosyokültürel unsurları Türk resmine taşıdığı yıllarda Mahmut Makal'ın (1930) 1950'de yayımladığı Bizim Köy romanıyla birlikte köy edebiyatı denilen bir tür oluşmaya başlar $^{55}$

1950'li yıllarda, sanatta bireyselleşme ve özgürleşme çabaları olarak karşımıza çıkan hiçbir gruba bağlı olmadan yoğun bir sanatçı çabasıyla var olmayı seçen sanatçılar çoğalmıştır. 1950 ve 1960'lı yıllarda Paris sosyal hayatını resimleriyle anlatan Fikret Mualla (1903-1967), Bistro/Yemek adlı çalışmasında (F.13) sarı rengin hâkim olduğu bir kompozisyonda çeşitli yiyeceklerle ve içkiyle donatılmış bir yemek masasında yemek yiyen beş figür betimlenmiştir. Masa üzerinde yer alan servislerin zengin bir görünüm sunduğu yapıt, evden ziyade restoran izlenimi verir. Bu resimler Paris’ten bir kesit sunarken, bize bir şekilde Batı yemek ve sofra düzenine olan hayranlığını da yansıtır.

55 İnci Aydın Çolak, İmge ve İmaj Türkiye'de Resim ve Edebiyatta Ortak Dil, Corpus Yayınları, İstanbul 2019, s. 254. 


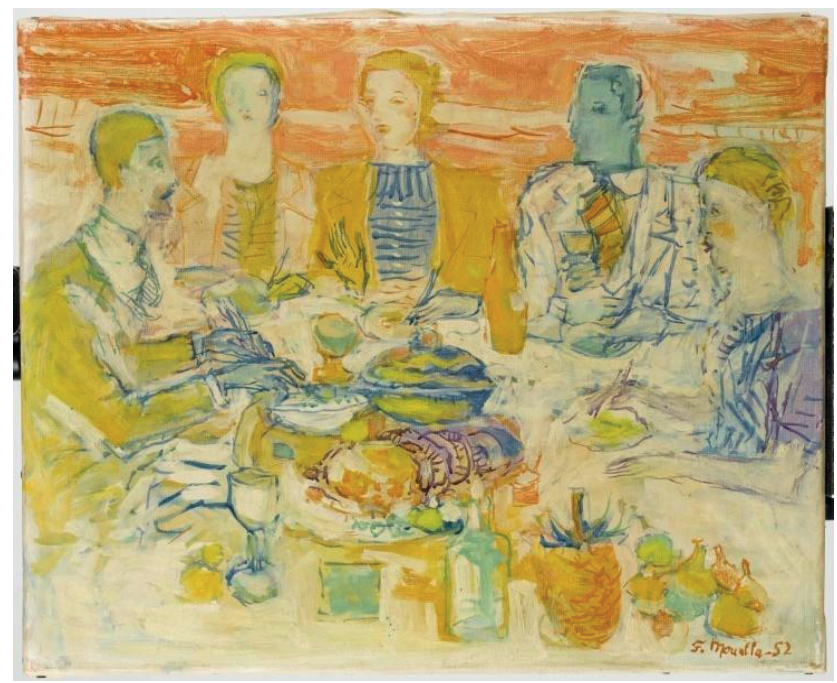

F. 13: Fikret Mualla, Bistro/Yemek, 1952, Tuval üzerine yağlıboya, $37 \times 45 \mathrm{~cm}$, Sabanc1 koleksiyonu, (Kıymet Giray, Sabancı Üniversitesi Sakıp Sabancı Müzesi Resim

Koleksiyonundan Seçmeler, Sabancı Üniversitesi Sakıp Sabancı Müzesi, Akbank, İstanbul 2002, s.213)

Türkiye'de Batı sanatıyla görsel anlamda tam bir paralellik 1950'lerden itibaren izlenmeye başlanacaktır. Sanatçıların bireysel girişimlerle farklı eğilimler peşinde olmaları bu yıllara rastlar. Tüm dünyada yükselen Amerika kaynaklı bir eğilim ile soyut sanat ülkemizde de etkili olmaya başlar. 1950’lerden sonra Türk resminin soyutlama ve soyuta yönelmesi ve sonrasında da kavramsal işlerin ele alınması yemek ve sofra resimlerinin başka göstergelerle okunmasına neden olur. 1960 sonrasında hızlı kentleşme, toplumsal dalgalanmalar sanatı da etkilemişsir.

\section{Sonuç}

Yemek ve sofra kültürü sosyal, ekonomik ve kültürel pek çok olguyu bünyesinde barındırır. Sürekli değişim içinde hareketli dinamiklere sahip olsa da toplumların kültürel kimliklerinin aktarımında oldukça önemli rol oynar. Nitekim Osmanlı mutfağından Cumhuriyet mutfağına geçiş sürecinde modernleşme olgusunun getirdiği yaşam pratikleri içindeki yenilikler ve çelişkiler dönemin görsel ve yazın dünyasında belgesel nitelikte eserlerle aktarılır. Bu çalışmalar kimi zaman Refik Halid Karay'ın İstanbul'un Bir Yüzü romanında olduğu gibi yeni ve eski adetlerle sofra düzenindeki ikiliği kimi zaman sosyal statüyü, Recaizade Mahmud Ekrem'de olduğu gibi kimi zaman yanlış Batılılaşmanın ifadesi ile doludur. Türk resminde ise yemek ve sofra konusunun vurgusu romanlardaki kadar yoğun değildir. Özellikle figür ve toplumsal kodların dışında kalan konuların betimleri dönemin sanatçılarınca uzun yıllar soru işareti ile karşılanmış, ancak 20. yüzyılın ilk yıllarında betimlenen konular arasında yer almıştır. Her ne kadar başka bir tür resmi olsalar da Türk resminde mutfağa giren meyvelerin ilk betimleri 
Natürmort resimlerde karşımıza çıkar. Batı resminde ise günlük yaşam ile sıkı sıkıya ilişkili olup, Rönesans'tan itibaren betimlenmeye başlar. Türk resminde ise ilk sofra betimi Ali Rıza Toroslu'ya ait olan Iftar Sofrası resmi ile başlar, 1914 Kuşağı ressamları ile devam eder. 20. yüzyılın ressamları ile aile ortamında sıcak yemek sofralarına dönüşür. Eşref Üren, Melahat Üren ve Ziya Keseroğlu'nun çalışmaları samimi ev ortamında yenilen yemek sofralarını betimler. Cevat Dereli'nin, Ístihsal (F.11) ve Turgut Zaim'in Yörükler Köyü resminde (F.12) kırsal yaşama ait sofra betimleri idealize edilerek hala geleneksel yönü ile sofranın kırsal bölgede devam ettiğine işaret eder. 1950 'lerden sonra tüm dünyada yükselen soyut sanat etkisi ile Türk resminin soyutlama ve soyuta yönelmesi ve sonrasında da kavramsal işlerin ele alınması ile yemek ve sofra resimlerinin başka göstergelerle okunmasına neden olur.

1960’l1 yıllar Türk sanat ortamına başka bir dönüşüm getirir öyle ki bu yıllarda sanata devletin desteği azalırken özel kurumlar açılmaya başlamış, toplum ise yeni bir dönüşüm sürecine girmiştir. 1980 sonrası ise dönüşüm sadece biçimsel değil, kavramsal olarak da gerçekleşecek ve günümüze kadar uzanan süreçte farklı toplumsal dinamiklerle beslenecektir.

Hakem Değerlendirmesi: Dış bağımsız.

Çıkar Çatışması: Yazarlar çıkar çatışması bildirmemiştir.

Finansal Destek: Yazarlar bu çalışma için finansal destek almadığını beyan etmiştir.

Peer-review: Externally peer-reviewed.

Conflict of Interest: The authors have no conflict of interest to declare.

Grant Support: The authors declared that this study has received no financial support.

\section{Kaynakça/References}

\section{Arşiv Belgesi}

BOA, HH. d. 1060, H. 20 Eylül 1327 / M. 6 Ekim 1909.

MSA. d. 3842 Hazine-i Hassa İnşaat ve Tamirat Haftalık Amele Jurnalleri, sene: 1308, sıra no: 1

Yıldız Albümleri, İstanbul Üniversitesi Nadir Eserler Kütüphanesi, 90614-0010.

\section{Diğer Kaynaklar}

Abir, Nihan, Siniden Masaya: Türk Romanında Sofra, Mimar Sinan Güzel Sanatlar Üniversitesi, Sosyal Bilimler Enstitüsü, Türk Dili ve Edebiyatı Anabilim Dalı Yeni Türk Edebiyatı Programı (Yayımlanmamış) Doktora Tezi, İstanbul 2018.

Ahmed Cavid, Tercüme-i Kenzü’l-İstiha 15.Yüzyıldan Bir Mutfak Sözlüğü, (Der.Priscilla Mary Işıı, Seyit Ali Kahraman), Kitap Yayınevi, İstanbul 2006.

Ayverdi, Sâmiha, İbrâhim Efendi Konağı, Kubbealtı, İstanbul 2009,

Baytar, İlona, “19. Yüzyıl Osmanlı Saraylarına Ait Dekorasyon Katalogları”, Sanat Tarihi Yıllı̆̆ı, Sayı 24, İstanbul 2016, s. 1-24. 
Berk, İlhan, Levent Çalıkoğlu, Ferit Edgü, Turan Erol, Murat Ural, Yurt Gezileri ve Yurt Resimleri, Milli Reasürans Yayınları, İstanbul 1998.

Beykal, Canan, "Hoca Ali Rıza”, Sanat Dünyamız, Kış, Sayı 97, İstanbul 2006, s. 15-27.

Coşansel, Demet, “19. Yüzyılda Osmanlı Sarayı'nda Mutfak Gelenekleri ve Sofra Düzeni”, 150 Yılın Sessiz Tanıkları Saray Porselinden İzler, (Haz. İ. Baytar), Milli Saraylar Yayınları, İstanbul 2007, s.25-36.

Cömert, Bedrettin, Giotto'nun Sanatı, De Ki Yayınları, İstanbul 2018.

Çalışır, Deniz, “İftar Sofrası: Sanatçısı Kim?”, Sanat Tarihi Yıllı̆̆ı, Sayı: XVII, İstanbul Üniversitesi Edebiyat Fakültesi Sanat Tarihi Araştırma Merkezi, İstanbul 2011 [Baskı Tarihi: 2012], s.27-39

Çolak, İnci Aydın, İmge ve İmaj Türkiye'de Resim ve Edebiyatta Ortak Dil, Corpus Yayınları, İstanbul 2019. Dranas, Ahmet Muhip, "Şeker Ahmet Paşa”, Güzel Sanatlar Dergisi; Şeker Ahmed Paşa, (Haz. Ö. Taşdelen, İ. Baytar), Milli Saraylar, İstanbul 2007, s. 195-198.

Dernschwam, Hans, İstanbul ve Anadolu’ya Seyahat Günlüğü, Kültür ve Turizm Bakanlığı, Ankara 1987. Dürrüoğlu, Ahmet, Şeker Ahmet Pașa, Eroğlu Matbaası, Ankara 1962.

Fahriye, Ayşe, Ev Kadını, (Yay. Haz. Turgut Kut), Çiya Yayınları, İstanbul 2018.

Faroqhi, Suraiya, Osmanlı Kültürü ve Gündelik Yaşam Ortaçağdan Yirminci Yüzyıla, (Çev. Elif Kılıç), Tarih Vakfi Yayınları, İstanbul 2005.

Germaner, Semra, "Süleyman Seyyid'in Resimlerinde İstanbul Bahçelerinden Çiçekler", P Sanat Kültür Antika, S.13 Bahar 1999, s.126-131.

Giray, Kıymet, Sabancı Üniversitesi Sakıp Sabancı Müzesi Resim Koleksiyonundan Seçmeler, Sabancı Üniversitesi Sakıp Sabanc1 Müzesi, Akbank, İstanbul 2002, s.198.

Gören, Ahmet Kamil, “(Şeker) Ahmed Ali Paşa’yı Yazmak”, Şeker Ahmed Paşa 1841-1907, (Haz. Ö.Taşdelen, İ.Baytar), TBMM- Milli Saraylar Daire Başkanlığı, İstanbul 2008, s.17-69.

Gören, Ahmet Kamil, “Türk Resminin Önemli Bir Odağı: Saray Koleksiyonu”, İhtişam ve Tevazu Padişahın

Ressam Kulları, TBMM Milli Saraylar Daire Başkanlığı, İstanbul 2012, s. 15-39.

Gürpınar, Hüseyin Rahmi, Şıpsevdi, Özgür Yay., 11.bs., İstanbul 2014.

İrez, Feryal, "Belgeler Iş̧ı̆ıında Son Alman İmparatoru II. Wilhelm’i Konuk Eden Bir Kasr-1 Hümâyûn;

Şale”, İki Dost Hükümdar Sultan II. Abdülhamid-Kaiser II. Wilhelm, (Haz. İ. Baytar), Milli Saraylar Yayınları, İstanbul 2009, s. 47-57.

İskender, Kemal, “Ölü Doğa”, Eczacıbaşı Sanat Ansiklopedisi, C. III, YEM Yayınları, İstanbul 1997, s. 1406-1407.

Karateke, Hakan T., Padişahım Çok Yaşa! Osmanıı Devletini Son Yüzyılında Merasimler, Kitap Yayınevi, İstanbul 2004.

Karay, Refik Halid, Ekmek Elden Su Gölden, İnkılâp ve Aka Yay., İstanbul 1985.

Karay, Refik Halid, İstanbul'un Bir Yüzü, İnkılâp Yay., 8. Bsk., İstanbul 2017.

Karay, Refik Halid, Mutfak Zevkinin Son Günleri, Haz. Tuncay Birkan, İnkılâp Yay., İstanbul 2014.

Karay, Refik Halid, Nesil Üç Hayat, İnkılap Kitabevi, İstanbul 2010.

Lèvi-Strauss, Claude, "Le Triangle Culinaire”, L'Arc, n.26, 1965.

Malaguzzi, Silvia, Food and Feasting Art, translated by Brian Phillips, The J.Paul Getty Museum, Los Angeles, Hong Kong 2008. 
Mehmed Kâmil, Melceü’t Tabbâhîn Aş̧̧ıların Sığınağı, (Günay Kut, Turgut Kut), Türkiye Yazma Eserler Kurumu Başkanlığı, İstanbul 2015.

Muhammed bin Mahmûd Şirvanî, 15. Yüzyıl Osmanlı Mutfağı, (Der. Mustafa Argunşah, Müjgan Çakır), Risale Yayınları, İstanbul 2018.

Naci, Elif, ““d’ Grubu”, Ankara Sanat, Y11:8, Say1:88, Ağustos 1973, Ankara Ağustos 1973, s.8.

Okkalı, İlkay Canan, Türk Resminde İç Mekân Resimleri (1880-1950'li Yıllar),İstanbul Üniversitesi Sosyal Bilimler Enstitüsü Sanat Tarihi Anabilim Dalı (Yayımlanmamış) Doktora Tezi, İstanbul 2014.

Okkalı, İlkay Canan, "Renkli Bir Yuva: Eşref Üren ve Melahat Üren’in Resimlerinde Ev”, Uluslararası Geleneksel Sanatlar Sempozyumu Bildiri Kitabı 20-21 Nisan 2017, Trabzon 2017, s.509-517.

Onaran, Burak, Mutfak Tarih Yemeğin Politik Serüveni, İletişim Yayınları, İstanbul 2015.

Samancı, Özge, “İmparatorluğun Son Döneminde İstanbul ve Osmanlı Saray Mutfak Kültürü”, Türk Mutfağı, Kültür ve Turizm Bakanlığı Yayınları, Ankara 2015, s. 199-217.

Saz, Leyla, Anılar 19. Yüzyılda Saray Haremi, Cumhuriyet Kitapları, İstanbul 2010.

Şerifoğlu, Ömer Faruk, “Bedri Rahmi Eyüboğlu Yüz Yaşında”, Bedri Rahmi Eyüboğlu, (Ed. Ömer Faruk Şerifoğlu), Ankara, T.C. Kültür ve Turizm Bakanlığı Yayınları, 2011, s. 12-15.

Tansuğ, Sezer, "Resim Sanatımızda Ortaya Çıkan Yeni Bir Gerçek: 19. Yüzyı1 Sonu Foto-Yorumcuları”, Çă̆daş

Türk Sanatına Temel Yaklaşımlar, (1.bs.), Bilgi Yayınevi, İstanbul 1997, s.39-44.

Tatlıcı, Gizem, Görsel Belleğin İzinde Türk Resminde Yemek Kültürü, Işık Üniversitesi Sosyal Bilimler Enstitüsü Sanat Bilimi Programı (Yayımlanmamış) Doktora Tezi, İstanbul 2018.

Ünsal, Artun-Beyhan Gence Ünsal, İstanbul'un Lezzet Tarihi, NTV Yayınları, İstanbul 2011.

Ünsal, Artun, Osmanlı Mutfağı, Yemek Kitabı, (Haz. M. Sabri Koz), Kitabevi Yayınları, İstanbul 2008, s. 128-158.

https://www.louvre.fr/en/oeuvre-notices/wedding-feast-cana (Erişim Tarihi 11.05.2020) 